\title{
Fundamental research questions in subterranean biology
}

\section{Mammola, Stefano}

2020-12

Mammola , S , Amorim , I R, Bichuette, M E , Borges , P A V , Cheeptham , N , Cooper , S J B , Culver , D C , Deharveng , L, Eme, D , Ferreira, R L , Fiser , C , Fiser , Z, Fong , D W , Griebler , C , Jeffery , W R, Jugovic , J , Kowalko , J E , Lilley , T M , Malard , F , Manenti , R, Martinez , A , Meierhofer , M B , Niemiller , M L , Northup , D E , Pellegrini , T G , Pipan , $T$, Protas , M , Reboleira , A S P S , Venarsky , M P , Wynne , J J , Zagmajster , M \& Cardoso , P 2020 , ' Fundamental research questions in subterranean biology ' , Biological Reviews , vol. 95 , no. 6 , pp. 1855-1872 . https://doi.org/10.1111/brv.12642

http://hdl.handle.net/10138/333518

https://doi.org/10.1111/brv.12642

acceptedVersion

Downloaded from Helda, University of Helsinki institutional repository.

This is an electronic reprint of the original article.

This reprint may differ from the original in pagination and typographic detail.

Please cite the original version. 
1 This is the accepted version of the following article: FULL CITE, which has been

2 published in final form at [10.1111/brv.12642]. This article may be used for non-

3 commercial purposes in accordance with the Wiley Self-Archiving Policy

4 [http://www.wileyauthors.com/self-archiving].

5

\section{Fundamental research questions in subterranean biology}

8 Stefano Mammola ${ }^{1,2, *}$, Isabel R. Amorim ${ }^{3}$, Maria E. Bichuette ${ }^{4}$, Paulo A. V.

9 Borges $^{3}$, Naowarat Cheeptham ${ }^{5}$, Steven J.B. Cooper ${ }^{6,7}$, David C. Culver ${ }^{8}$, Louis

10 Deharveng $^{9}$, David Eme ${ }^{10}$, Rodrigo Lopes Ferreira ${ }^{11}$, Cene Fišer ${ }^{12}$, Žiga Fišer ${ }^{12}$,

11 Daniel W. Fong ${ }^{13}$, Christian Griebler ${ }^{14}$, William R. Jeffery ${ }^{15}$, Jure Jugovic ${ }^{16}$,

12 Johanna E. Kowalko ${ }^{17}$, Thomas M Lilley ${ }^{18}$, Florian Malard ${ }^{19}$, Raoul Manenti ${ }^{20}$,

13 Alejandro Martínez ${ }^{2}$, Melissa B. Meierhofer ${ }^{18,21}$, Matthew L. Niemiller ${ }^{22}$, Diana E.

14 Northup $^{23}$, Thais G. Pellegrini ${ }^{11}$, Tanja Pipan ${ }^{24,25}$, Meredith Protas ${ }^{26}$, Ana Sofia P.

S. Reboleira ${ }^{27}$, Michael P. Venarsky ${ }^{28}$, J. Judson Wynne ${ }^{29}$, Maja Zagmajster ${ }^{12}$ and

Pedro Cardoso ${ }^{1, *}$

${ }^{1}$ Laboratory for Integrative Biodiversity Research (LIBRe), Finnish Museum of Natural History (LUOMUS), University of Helsinki, Pohjoinen Rautatiekatu 13, 00100 Helsinki, Finland

${ }^{2}$ Molecular Ecology Group (MEG), Water Research Institute (IRSA), National Research Council 
$22{ }^{3}$ cE3c-Centre for Ecology, Evolution and Environmental Changes / Azorean Biodiversity

23 Group and Universidade dos Açores, Faculty of Agrarian and Environmental Sciences. Rua

24 Capitão João d'Àvila, Pico da Urze, 9700-042 Angra do Heroísmo, Azores, Portugal.

$25{ }^{4}$ Laboratory of Subterranean Studies, Federal University of São Carlos, Rodovia Washington

26 Luís km 235, 13565-905 São Carlos, São Paulo, Brazil

$27{ }^{5}$ Department of Biological Sciences, Faculty of Science, Thompson Rivers University, 805 TRU

28 Way, Kamloops, BC, Canada

$29{ }^{6}$ Evolutionary Biology Unit, South Australian Museum, North Terrace, Adelaide, South Australia

30 5000, Australia

$31{ }^{7}$ Australian Centre for Evolutionary Biology and Biodiversity, and Environment Institute, School

32 of Biological Sciences, University of Adelaide, Adelaide, South Australia 5005, Australia

$33{ }^{8}$ Department of Environmental Science, American University, 4400 Massachusetts Avenue, N.W.,

34 Washington DC 20016, USA

$35{ }^{9}$ UMR7205 - ISYEB, Museum national d'Histoire naturelle, 45 rue Buffon (CP50), 75005 Paris,

36 France

$37{ }^{10}$ IFREMER centre Atlantique, unité Ecologie et Modèles pour l'Halieutique, Rue de l'Île d'Yeu,

38 44980, Nantes, France

$39{ }^{11}$ Center of Studies in Subterranean Biology, Biology Department, Federal University of Lavras,

40 Campus Universitário, CEP 37202-553, Lavras, Minas Gerais, Brazil

$41{ }^{12}$ SubBio Lab, Department of Biology, Biotechnical Faculty, University of Ljubljana,

42 Jamnikarjeva 101, Ljubljana, SI-1000, PO BOX 2995, Slovenia

$43{ }^{13}$ Department of Biology, American University, 4400 Massachusetts Avenue, N.W.

44 Washington DC 20016, USA 
${ }^{14}$ University of Vienna, Department of Functional and Evolutionary Ecology, Division of Limnology, Althanstrasse 14, 1090 Vienna

${ }^{15}$ Department of Biology, University of Maryland, College Park, MD, Maryland 20742, USA

${ }^{16}$ Department of Biodiversity, Faculty of Mathematics, Natural Sciences and Information

Technologies, University of Primorska, Glagoljaška 8, Koper, SI-6000, Slovenia

${ }^{17}$ Harriet L. Wilkes Honors College, Florida Atlantic University, 5353 Parkside Dr, Jupiter, FL 33458, USA

${ }^{18}$ BatLab Finland, Finnish Museum of Natural History, University of Helsinki, Pohjoinen Rautatiekatu 13, 00100 Helsinki, Finland

${ }^{19}$ UMR5023 Ecologie des Hydrosystèmes Naturels et Anthropisés, Univ. Lyon 1, ENTPE, CNRS, Univ. de Lyon, Bat. Forel, 6 rue Raphaël Dubois, 69622 Villeurbanne cedex, France

${ }^{20}$ Department of Environmental Science and Policy, Università degli Studi di Milano, Via Celoria 26, 20113 Milano, Italy

${ }^{21}$ Department of Rangeland, Wildlife and Fisheries Management, Texas A\&M University, 534 John Kimbrough Blvd., College Station, TX 77843, USA

${ }^{22}$ Department of Biological Sciences, The University of Alabama in Huntsville, 301 Sparkman

Drive NW, Huntsville, AL 35899, USA

${ }^{23}$ Department of Biology, University of New Mexico, Albuquerque, NM 87131-0001, USA

${ }^{24}$ ZRC SAZU Karst Research Institute, Novi trg 2, SI-1000 Ljubljana, Slovenia

${ }^{25}$ UNESCO Chair on Karst Education, University of Nova Gorica, Vipavska cesta, 5000 Nova Gorica, Slovenia

${ }^{26}$ Department of Natural Sciences and Mathematics, Domenicas University of California, 50 Acacia Avenue, San Rafael, CA 94901, USA 
82

${ }^{27}$ Natural History Museum of Denmark, University of Copenhagen, Universitetsparken 15, 2100 Copenhagen, Denmark

${ }^{28}$ Australian Rivers Institute, Griffith University, 170 Kessels Road, Nathan 4111, Queensland, Australia

${ }^{29}$ Department of Biological Sciences, Center for Adaptable Western Landscapes, Northern Arizona University, Box 5640, Flagstaff, AZ 86011, US

\section{Running title: Scanning the horizon of subterranean biology}

*Authors for correspondence: S. Mammola (E-mail: stefano.mammola@ @elsinki.fi; stefano.mammola@cnr.it; Tel.: +39 0323 518363; Water Research Institute, National Research Council of Italy, Corso Tonolli, 50, 28922 Pallanza, Italy) and P. Cardoso (E-mail: pedro.cardoso@helsinki.fi; Tel.: +358503185685; Finnish Museum of Natural History, Pohjoinen Rautatiekatu 13, 00100 Helsinki, Finland).

\section{ABSTRACT}

Five decades ago, a landmark paper in Science titled The Cave Environment heralded caves as ideal natural experimental laboratories in which to develop and address general questions in geology, ecology, biogeography, and evolutionary biology. Although the 'caves as laboratory' paradigm has since been advocated by subterranean biologists, there are few examples of studies that successfully translated their results into general principles. The contemporary era of big data, modelling tools, and revolutionary advances in genetics and (meta)genomics provides an opportunity to revisit unresolved questions and challenges, as well as examine promising new 
91 avenues of research in subterranean biology. Accordingly, we have developed a roadmap to

92 guide future research endeavours in subterranean biology by adapting a well-established

93 methodology of 'horizon scanning' to identify the highest priority research questions across six

94 subject areas. Based on the expert opinion of 30 scientists from around the globe with

95 complementary expertise and of different academic ages, we assembled an initial list of 258

96 fundamental questions concentrating on macroecology and microbial ecology, adaptation,

97 evolution, and conservation. Subsequently, through online surveys, 130 subterranean biologists

98 with various backgrounds assisted us in reducing our list to 50 top-priority questions. These

99 research questions are broad in scope and ready to be addressed in the next decade. We believe

100 this exercise will stimulate research towards a deeper understanding of subterranean biology and

101 foster hypothesis-driven studies likely to resonate broadly from the traditional boundaries of this

102 field.

103

104 Key words: biospeleology, cave biology, expert opinion, groundwater, horizon scanning,

105 research questions, stygofauna, troglobionts.

106

107 CONTENTS

108 I. Introduction

109 II. Horizon scanning protocol

$110 \quad$ (1) Initial list assembly

111 (2) Voting procedure and selection of 50 top-priority questions

112 (3) Caveats on interpretation

113 III. Summary of the horizon scan 
IV. Adaptation

115 V. Origin and evolution

VI. Community ecology

VII. Macroecology and biogeography

116 VIII. Conservation

117 IX. Microbiology and applied topics

118 X. Conclusions

119 XI. Acknowledgements

120 XII. References

121 XIII. Supporting information

122

123

\section{INTRODUCTION}

124 In the era of the Internet, social media, and open-access mega-journals, the amount of accessible 125 scientific information is overwhelming (Landhuis, 2016; Wakeling et al., 2016; Fire \& Guestrin, 126 2019; Jarić et al., 2020). It is estimated that more than 50 million peer-reviewed scientific papers 127 exist (Jinha, 2010) and about 1.5 million new articles are published every year (Laurance et al., 128 2013). To capitalize on the volume of this information and make the most of it (e.g. Ioannidis, 129 2005; Jeschke et al., 2019), it is becoming increasingly important for scientists to explore 130 effective ways to capture the latest advances in their field or related fields of research. Horizon 131 scanning - i.e. the systematic examination of information to identify emerging issues and 132 opportunities in a given research area - has become a useful tool to summarize and determine 133 research priorities and agendas (Sutherland et al., 2011). The most important questions in 134 ecology (Sutherland et al., 2013; McGill et al., 2019), island biogeography (Patiño et al., 2017), 
and microbiology (Antwis et al., 2017), the annual identification of emerging issues in global conservation (Sutherland et al., 2020), as well as the 100 articles that every ecologist should read (Courchamp \& Bradshaw, 2018), are all instructive examples where horizon scanning has successfully synthesized trends or highlighted the most promising future research avenues. Fifty years ago, in a landmark Science paper titled The Cave Environment, Poulson \& White (1969) heralded caves as 'natural laboratories', i.e. simplified settings that can be used to understand the principles governing the dynamics of more complex environments. Characterized by stringent environmental constraints and simple communities, subterranean habitats have been regarded as ideal systems for investigating many of the unresolved questions in ecology, biogeography, and evolutionary biology (Juan et al., 2010; Sánchez-Fernández et al., 2018; Mammola, 2019). Scientists have also studied subterranean organisms to understand human diseases such as autism (Yoshizawa et al., 2018), diabetes (Riddle et al., 2018), and cancer (Gatenby, Gillies \& Brown, 2011), to investigate the engineering potential of biologically inspired materials (Lepore et al., 2012), and to discover new drugs and pharmaceutical products (Cheeptham et al., 2013). Others have even looked at caves through the lens of astrobiology, showing that the subterranean microbiome might hold clues to life beyond Earth (Northup et al., 2011; Popa et al., 2011).

Although the 'caves as laboratory' paradigm is often advocated by subterranean biologists, examples of studies that have successfully translated their results into general principles remain few in number. Five decades after Poulson \& White (1969), subterranean biology is entering a new research era dominated by big data (Zagmajster et al., 2019), modelling tools (Flôres et al., 2013; Mammola \& Leroy, 2018), and increasingly cheaper molecular approaches (Pérez-Moreno, Iliffe \& Bracken-Grissom, 2016; Lefébure et al., 2017). 
158 Concomitantly, we are facing a global crisis that is negatively impacting subterranean

159 biodiversity (Mammola et al., 2019b; Boulton, 2020). Therefore, the time is ripe to review the

160 outstanding challenges faced by this broad-in-scope discipline, as well as promising new

161 research avenues where subterranean-based studies may be helpful in answering general and

162 broadly scoped questions. Because gathering multiple views on such an extensive subject is

163 difficult, we relied on the well-established methodology of horizon scanning to identify 50

164 fundamental, but unresolved questions in subterranean biology. With this intellectual exercise,

165 we aimed to develop a roadmap that will guide future research endeavours and stimulate

166 hypothesis-driven studies likely to resonate beyond the boundaries of this discipline.

168 II. HORIZON SCANNING PROTOCOL

169 (1) Initial list assembly

170 We used horizon scanning methodology (Sutherland et al., 2011) and adapted the approach

171 developed by Patiño et al. (2017) to identify priority research questions in subterranean biology.

172 Survey coordinators (S.M. and P.C.) identified seven subject areas within the subterranean

173 biology discipline (Table 1), namely: (1) Adaptation, (2) Origin and evolution, (3) Community

174 ecology, (4) Macroecology and biogeography, (5) Conservation biology, (6) Microbiology and

175 applied topics, and (7) Other topics. We included the latter subject area to cover additional topics

176 or ideas that departed from the six core subject areas and may have been overlooked. For each

177 subject area, survey coordinators invited a senior researcher (highlighted with asterisks in Table

178 1) to act as panel coordinator, with the task of establishing an international panel of experts to

179 identify and formulate a set of fundamental questions. Each panel coordinator selected and

180 invited three or four members to join their panel, which included at least one early-career 
scientist (i.e. a postdoc or researcher with less than 10 years of experience) to obtain a multigenerational perspective on the different topics. Survey coordinators encouraged panel members

to consult broadly with colleagues and select additional researchers to join their panels if deemed important in providing complementary expertise. In assembling the panels, our goal was to maximize multidisciplinarity, while ensuring that research interests within the seven panels covered a broad array of geographic areas, model organisms, and networks of international collaborators. Members of each panel identified at least 20 questions that they viewed as fundamental within their subject area and thus likely to advance the field significantly. In total, we assembled 258 questions, which were screened for duplication or ambiguity by the survey coordinators. In this phase, survey coordinators purged most subterranean-specific jargon from questions and homogenized wording to ensure that all questions were presented in a clear and straightforward manner. Therefore, throughout the survey we operated under the assumption that all questions were characterized by a similar degree of readability (PlavénSigray et al., 2017). After the cleaning procedure and removal of duplicate questions, we assembled a final list of 211 survey questions (hereafter 'List \#1'). In assembling List \#1, we subsumed questions identified by the panel focusing on 'Other topics' into the six main subject areas.

\section{(2) Voting procedure and selection of 50 top-priority questions}

We subjected List \#1 to an initial round of online voting by all panel members (Survey \#1) to select the most voted 20 questions for each of the six subject areas (Fig. 1). Voting was a binary choice, whereby participants scored each question as either of 'major' or 'minor' importance. We randomized question order for each participant. We repeated this voting protocol in all 
subsequent online surveys. Each panel member voted on all questions irrespective of subject area, although votes by panelists on their subject area were disregarded in the final ranking of Survey \#1. As a result, survey coordinators culled List \#1 to the 120 most-voted questions (20 questions from each of six subject areas), referred to as List \#2, thus balancing the number of questions in subsequent voting rounds.

We then subjected List \#2 to online voting (Survey \#2) by inviting a broad community of subterranean biologists including $c a .170$ members of the International Society on Subterranean Biology (ISSB), ca. 50 members of the European Cave Organism Network, $c a .100$ members of the Anchialine mailing list, as well as other working groups and email listservs related to subterranean biology that we could identify (e.g. national biospeleological groups). Note that members of these different groups often overlapped and some of the emails were no longer active. We estimated that Survey \#2 reached an upper boundary of between 200 and 250 unique recipients. Of these, 133 recipients completed the online survey. At the end of Survey \#2, we gave participants the opportunity to submit one additional question if they felt this question was missing from List \#2. Thus, 25 additional questions were added to the third list of questions (List \#3). Questions in List \#3 were voted on by all panel members (Survey \#3), and then ranked (by percentage of 'major importance' votes per question) together with the 120 questions from List \#2. Finally, we selected the highest ranking questions to assemble a list of 50 top-priority questions.

\section{(3) Caveats on interpretation}

Some general caveats should be recognized when interpreting the results of any horizon scanning survey (e.g. Sutherland et al., 2011, 2013; Seddon et al., 2014; Patiño et al., 2017). First, the 
227 background knowledge and intellectual passions of the experts involved may introduce

228 subjectivity in the formulation of the initial list of topics and questions. Second, subjectivity

229 likely plays a role throughout the voting process, as any voting outcome may be affected by the

230 interests of a particular group of participants. In our case, potential biases in the composition of

231 subterranean biologists sampled may have influenced the final selection of the top-priority

232 questions to an extent difficult to quantify precisely. For example, questions related to

233 microbiology received the lowest share of 'major importance' votes (mean \pm SD: $0.69 \pm 0.01$ ). It

234 is understood that microbiology topics are not less important or timely, it is simply that

235 microbiologists are probably underrepresented in the subterranean biology community. Also, an

236 imbalance in the expertise of participants may explain the substantial difference in how the

237 highest priority questions were parsed across the six subject areas - from four in 'Community

238

239

240

241

242

243

244

245

246

247 ecology' to 12 in 'Conservation biology'.

To address these potential shortcomings, we adopted four countermeasures. First, we increased the survey audience, by addressing the questionnaire to different groups and associations of subterranean biologists. Second, we diversified the expertise of panel members by including early-stage to mid- and late-career researchers from different disciplines, research laboratories, and geographic areas. Third, we included a seventh panel ('Other topics') specifically to fill the gaps in the initial composition of proposed questions. Indeed, it has been argued that in horizon scanning, the initial division into subject areas may limit lateral thinking (Sutherland et al., 2013). Finally, by allowing voters to suggest additional questions when voting in the survey, we were able to capture the range of priority topics better.

We are confident these practices minimized some of the biases inherent to this study. Importantly, we believe this 50 top-priority survey served to highlight some of the most timely 
and challenging areas of interest in current and future research, rather than providing a comprehensive synthesis of research needs in modern subterranean biology.

\section{SUMMARY OF THE HORIZON SCAN}

In Survey \#1, the percentage of 'major importance' votes ranged between $89 \%$ (top-voted question) and 4\% (least-voted question). In the extended online voting (Survey \#2), 133 voters participated, of which 71\% identified 'subterranean biology' as their primary field of research. Although voters' gender was slightly skewed toward males (76 men versus 57 women), deviation from the 1:1 male:female ratio was not significant $\left(\chi^{2}=2.71\right.$; d.f. $\left.=1 ; P=0.10\right)$, indicating that our sample was not gender-biased. $45 \%$ of survey voters were experienced researchers, with an academic age of more than 10 years since they earned their PhD, while $29 \%$ were researchers within 10 years from their $\mathrm{PhD} . \mathrm{PhD}$ and undergraduate students accounted for $16 \%$ of voters. The remaining $10 \%$ of participants were other professionals, such as research and field technicians or recreational cavers.

During Survey \#2, participants suggested 28 additional questions; three questions were duplicates and were thus excluded. The remaining 25 questions were evaluated during Survey \#3, and three made it to the 50 top-priority list. The lower threshold for questions was $67 \%$ of 'major importance' votes, whereas the top-voted question garnered 91\% votes (Fig. 1).

In the following, we present the 50 top-priority questions in subterranean biology according to the results of Surveys \#2 and \#3 (the full list of questions is provided as online supporting information in Appendix S1). For clarity, questions were compiled into our six subject areas. We provide information about each question's final rank (\#) and percentage of 'major importance' votes received (\%), and highlight the three questions suggested by the 
273 Survey \#2 participants with an asterisk (*). A glossary of terms is available in Table 2.

274

275 IV. ADAPTATION

276 Q1 - What are the drivers of adaptive evolution in caves? [\#1; 91\%]

277 Q2 - What are the main constraints to subterranean adaptation? [\#4; 83\%]

278 Q3 - What are the degrees of adaptive plasticity of organisms across different subterranean

279 environments? [\#9; 78\%]

280 Q4 - Which traits of subterranean organisms should be considered as 'adaptive'? [\#11; 78\%]

281 Q5 - How have morphological and behavioural traits co-evolved in subterranean organisms?

$282[\# 14 ; 76 \%]$

283 Q6 - What is the level and nature of reproductive isolation between cave and surface populations

284 and what reproductive barriers are typically involved? [\#19; 75\%]

285 Q7 - Do similar traits evolve repeatedly in subterranean organisms due to changes in the same

286 genes, genetic pathways, and/or developmental processes? [\#23; 73\%]

287 Q8 - Have subterranean species evolved a distinct set of convergent behaviours? [\#26; 72\%]

288 Q9 - Are there common developmental pathways that promote or constrain subterranean

289 adaptation? [\#29; 72\%]

290 Q10 - Do traits that constitute reproductive isolation evolve in the same way across independent

291 closely related subterranean populations or species? [\#42; 70\%]

292

293 The morphology of subterranean organisms, which show bizarre convergent adaptations even

294 across different animal phyla, has historically attracted the attention of generations of scientists

295 (Juan et al., 2010) including Charles Darwin (1859). Therefore, it is no surprise that subterranean 
biologists participating in this survey greatly valued the role of subterranean habitats as natural

297

laboratories for the study of adaptive evolution. Ten questions focusing on adaptation were included in our top-50 list (Fig. 1).

Colonization of suitable habitat is the initial event leading to subterranean adaptation (details in Section V). Whatever the mode or pathway, colonizers often experience a significant change upon entering the subterranean environment (i.e. complete darkness), which results in visual sensory deprivation, challenges in locating mates and food, limited or modified food resources, and physical barriers to dispersal. Adaptive responses to these factors may involve the action of selection on plastic traits already existing in the colonizers (i.e. phenotypic plasticity; Bilandžija et al., 2020), standing genetic variation, or new beneficial mutations. Understanding which of these environmental factors and adaptive responses play a primary role in subterranean adaptation, either acting alone or in various combinations, was the most important question (Q1) in our survey, selected by $91 \%$ of participants. Yet, given that some higher taxa are missing or understudied in caves (Culver \& Pipan, 2019), it remains unclear what are the main constraints to subterranean adaptation (Q2) and whether specific exaptations facilitate successful colonization events (see also Q11 in Section V). Resolving how many phenotypes of subterranean dwellers depend on genetic and developmental constraints (Q9), or reflect entrapment at local peaks in adaptive landscapes or recent invasions with insufficient time for selection to alter traits, is one of the future challenges for evolutionary biologists.

Additional high-priority questions were focused on subsequent refinements of the initial adaptive responses, such as the repertoire of adaptive plasticity (Q3), the degree to which preexisting genetic variation contributes to subterranean phenotypes, and which traits of subterranean organisms can be considered as adaptive (Q4). Historically, reduction or loss of 
319 traits such as eyes and pigmentation was thought to be driven by random mutations and genetic

320 drift or by natural selection, either directly or indirectly. This controversy has continued to the

321 present, with strong adaptationist (Carlini \& Fong, 2017) and non-adaptationist (Wilkens \&

322 Strecker, 2017) viewpoints. Depending on the species or ecological context, it is possible that all

323 of these mechanisms have roles in subterranean adaptation. Resolving this debate will require

324 explanations at the molecular, cellular, and developmental levels in multiple lineages (Jeffery,

325 2005), and the integration of this information to infer whether convergent traits evolve repeatedly

326 in subterranean animals due to changes in the same or different genes, genetic pathways, and

327 developmental processes (Q7). Answers to all these questions will contribute to our

328 understanding concerning why some species adapt rapidly and evolve when facing new

329 environmental conditions, inside or outside caves, which is a critical question given global

330 climate change (Walther et al., 2002). In turn, this could provide insights about adaptive

331 processes occurring in other ecological settings with a similar set of environmental conditions

332 (e.g. permanent darkness, constancy in climatic conditions, food scarcity), such as deep-sea

333 habitats (Trontelj, Borko \& Delić, 2019; Mammola, 2020).

334 Once survival in a subterranean habitat is ensured, the successful colonizers are subject to

335 adaptive morphological and behavioural (co-)evolution (Q5). Many behavioural changes are

336 probably influenced by the essential requirements of finding food and mates in darkness, and

337 may be convergent across different subterranean lineages (Q8). Also, some subterranean animals

338 suddenly attain a new status at the top trophic level and predator release occurs. For example, in

339 the Mexican tetra, Astyanax mexicanus (De Filippi) (Actinopterygii: Characidae), the workhorse

340 of adaptive evolution studies in caves (Jeffery, 2009; Wilkens \& Strecker, 2017; Torres-Paz et

$341 a l ., 2018)$, this new ecological status of an apex predator facilitated the evolution of a range of 
342 behaviours that may not be sustainable in a predator-limited surface environment (Yoshizawa et 343 al., 2010; Hyacinthe, Attia \& Rétaux, 2019).

344 Most subterranean organisms may also face subsequent invasions of their habitats by new 345 colonizers, of both former surface-dwelling conspecifics (if they are still extant) and other 346 competing species (e.g. Howarth et al., 2007; Wynne et al., 2014). Therefore, to understand

347 subterranean adaptations fully, it is crucial to explore the degree and nature of reproductive 348 isolation between the subterranean-adapted lineages and invading surface conspecifics (Q6). The 349 majority of subterranean animals probably arose through the process of ecological speciation in 350 which reproductive isolation evolved as a response to divergent selection between environments 351 (Niemiller, Fitzpatrick \& Miller, 2008; Mammola et al., 2018). Thus, many subterranean 352 adaptations should at least indirectly favour non-random mating between individuals of the 353 derived subterranean and ancestral surface populations. Understanding this will help to address

354 whether traits that constitute reproductive isolation evolve in the same way in independent 355 closely related subterranean populations or species (Q10), and therefore whether and how often 356 parallel speciation occurs in the subterranean realm. Ultimately, this would shed new light 357 concerning the intriguing hypothesis on the predictability of evolution (Blount, Lenski \& Losos, 358 2018).

\section{ORIGIN AND EVOLUTION}

Q11 - Which traits present in surface species (exaptations) facilitate successful subterranean colonization and adaptation? [\#12; 77\%] habitats? [\#13; 77\%] 
Q13 - What evolutionary processes most commonly triggered radiations of subterranean

366

367

368

369

370

371

372

373

374

375

376

377

378

379

380

381

382

383

384

385

386

387

organisms? [\#15; 76\%]

Q14 - Do subterranean organisms lack genetic variation and thus the ability to adapt to a changing environment? [\#16; 75\%]

Q15 - Does the timeline of subterranean evolution differ among taxa, types of subterranean habitats, different biogeographic areas, and different ecological settings? [\#22; 74\%]

Q16 - What are the impact(s) of biotic and abiotic factors on speciation? [\#28; 72\%]

Q17 - Why are some lineages successful at colonizing subterranean habitats while others are not? [\#35; 71\%]

Q18 - How old are subterranean species? [\#36; 71\%]

Q19 - The role of evolutionary processes (convergence/divergence/evolutionary stasis/parallelisms) in subterranean organisms: what are the most common evolutionary processes? [\#40; 70\%]

Q20 - Are shallow subterranean habitats a gateway to colonize deep zones and is the evolution of deep subterranean species conditioned with a colonization of shallow and later deeper zones? [\#41; 70\%]

Q21 - What is the rate of evolution of different subterranean traits and does the degree of subterranean adaptation correlate with duration of subterranean inhabitation? [\#44; 69\%]

Subterranean animals have long interested biologists as evolutionary models. Studies of these species have endeavoured to improve our understanding of evolution, its repeatability at the phenotypic (Friedrich, 2013; Porter \& Sumner-Rooney, 2018), physiological (Jones, Cooper \& Seymour, 2019), and molecular level (Leys et al., 2005; Bilandžija, Ćetković \& Jeffery, 2012; 
388 Niemiller et al., 2013), its reversibility (Copilaş-Ciocianu et al., 2018), and the role of drift in

389

390

391

392

393

394

395

396

397

398

399

400

401

402

403

404

405

406

407

408

409

410

morphological changes (Martínez et al., 2017; Wilkens, 2020). The eleven questions identified

highlight how, despite advances in the application of genetic tools and techniques in the last 50

years, fundamental questions regarding the origin and evolution of subterranean animals remain unanswered.

Two high-ranked questions (Q11 and Q17) focused on the traits that enable species to successfully colonize and adapt to subterranean habitats. Additional questions focused on the most common evolutionary processes (Q19), and the influence of biotic and abiotic factors (Q16) that lead to different patterns of diversification across subterranean lineages (Q12). Important subterranean radiations are known in all major taxonomic groups (Deharveng \& Bedos, 2019), but only a few of them have been well documented. These include Amphipoda (Zakšek et al., 2019), Collembola (Lukić et al., 2019), and Coleoptera (Leys et al., 2003; Faille et al., 2010; Njunjić et al., 2018). Which evolutionary processes best explain these radiations remains highly debated (Q13) and it would be particularly interesting to compare and contrast radiations of surface-dwelling plants and animals (Gillespie et al., 2020) with subterranean-adapted species to determine if any universal patterns exist. For many animal groups, subterranean species are commonly assumed to have evolved from surface species (Barr \& Holsinger, 1985; Peck \& Finston, 1993), but recent phylogenetic studies suggest that this assumption may not always apply (Faille et al., 2010; Juan et al., 2010; Leijs et al., 2012). Speciation and diversification may also occur within the confines of a subterranean habitat, a process referred to as 'endogenous diversification' (Trontelj, 2019). Moreover, some phylogenetic studies suggested that subterranean colonization is not an evolutionary dead end and surface species may actually arise from subterranean ancestors (Prendini, Francke \& Vignoli, 2010; Niemiller et al., 2013; Copilaş- 
411 Ciocianu et al., 2018). However, cases of endogenous speciation and 'subterranean to surface'

412 reversals are potentially confounded by extinction of surface lineages (Juan et al., 2010).

413 Therefore, new approaches are needed that avoid reliance on phylogenetic methods alone to

414 improve our understanding of these patterns.

415 Genetic variation enhances the ability of species to adapt and diversify. Additionally, it

416 has been shown that some subterranean species may contain high levels of neutral genetic

417 variation (Buhay \& Crandall, 2005; Guzik et al., 2009), but it is still unclear whether neutral

418 mutations equates to high levels of adaptive genetic variation. This underpins the question

419 whether subterranean species lack the ability to adapt to changing environments (Q14), including

420 increasing temperatures and the introduction of new pathogens (Mammola et al., 2019c). Such

421 hypotheses are obviously not exclusive to the subterranean environment. However, this

422 ecosystem does provide numerous examples of how low genetic variation was hypothesized to

423 be related to low adaptive capacity, a phenomenon more common underground than at the

424 surface (Konec et al., 2015; Lefébure et al., 2017; Fumey et al., 2018).

425 Understanding the timeline and direction of subterranean evolution, as well as the age of

426 subterranean species, featured prominently in several questions (Q15, Q18, Q20, Q21).

427 Advances in molecular clock calibration (Drummond et al., 2006) and genomic analyses (Pérez-

428 Moreno et al., 2016) are considerably promising and permit the development of robust time trees

429 (Pons et al., 2019). However, these analyses are limited by the availability of extant and fossil

430 taxa and the extinction of surface relatives; the latter makes it difficult to pinpoint the initial

431 colonization time of a subterranean habitat by a given species. This is particularly important for

432 ancient lineages of specialized subterranean organisms with marine origin, which often lack

433 surface-dwelling relatives and/or show low levels of fossilization (Pérez-Moreno et al., 2016). 
434 This is unfortunate because many of these basally branching lineages are required to reconstruct

435 trait evolution of major animal lineages (e.g. Johnson et al., 2012; Khodami et al., 2017; Lozano-

436 Fernandez et al., 2019).

437 The genetic basis underlying evolution of subterranean traits, and how they are shaped by

438 natural selection and/or neutral processes, are key factors in determining rates of subterranean

439 evolution (Q21). Considerable advances have been made through the study of model

440 subterranean species, especially Astyanax mexicanus and the freshwater isopod Asellus aquaticus

441 (L.) (Protas \& Jeffery, 2012). These species have several independent and recently evolved

442 subterranean populations, as well as extant surface populations, which can be hybridized in the

443 laboratory. Their features allow for the dissection of genes and mutations responsible for traits

444 related to subterranean life and provide information on the processes (e.g. selection or neutral

445 evolution) that shape their evolution. The role of neutral processes in the evolution of

446 subterranean animals has also been explored using alternative model systems (e.g. dytiscid

447 beetles and amblyopsid cavefishes). In both cases, species have been evolving underground for

448 millions of years, which is sufficient to enable the fixation of deleterious mutations in genes

449 under relaxed selection (Niemiller et al., 2013; Tierney et al., 2018). These model organisms

450 offer great potential to investigate major questions on the origin and evolution of subterranean

451 animals using comparative genomics, and thus may provide insights for similar processes in

452 other, non-subterranean, settings. 


\section{COMMUNITY ECOLOGY}

454 Q22 - What are the main ecological and ecosystem services provided by subterranean

455 populations and communities? [\#20; 75\%]

456 Q23 - What are the key food-web processes influencing subterranean community dynamics?

$457 \quad[\# 24 ; 73 \%]$

458 Q24 - How do stochastic events interact with long-term trends in subterranean ecosystems?

$459 \quad[\# 30 ; 72 \%]$

460 Q25 - How do basic life-history characteristics differ among subterranean communities and

461 between subterranean and surface communities? [\#33; 71\%]

Subterranean habitats are well-suited systems to address general problems in community ecology

464 (Mammola, 2019). Foremost, caves are often semi-closed environments extensively replicated across the Earth (Culver, 1970; Culver \& Pipan, 2019; Itescu, 2019; Mammola, 2019). Second, subterranean communities generally exhibit lower diversity and abundance of organisms than surface ones and are characterized by a bottom-truncated functional diversity (Gibert \& Deharveng, 2002), allowing us to disentangle the effect of abiotic conditions and biotic interactions in filtering species possessing specific traits within the community (Cardoso, 2012). Third, caves have some conspicuous environmental gradients from the surface towards the subsurface (Howarth, 1982; Tobin, Hutchins \& Schwartz, 2013; Mammola et al., 2019d), offering a mosaic structure of subterranean microhabitats defined by distinct habitat-filtering

473 properties (Trontelj, Blejec \& Fišer, 2012; Mammola et al., 2020). 
model systems for evolutionary studies (Juan et al., 2010), and secondarily used caves as

477 convenient settings to address fundamental ecological questions (Mammola, 2019). Yet, these

four questions fell within general and timely areas of current ecological research (see Sutherland 479 et al., 2013).

The top-ranked question underscored the importance of services provided to humans by

481

482

483

484

485

486

487

488

489

490

491

492

493

494

495

496

497

498 subterranean species and ecosystems (Q22), rather than on theoretical aspects of community

ecology. Examples of ecosystem services provided by subterranean ecosystems include

pollination, seed dispersal, and agricultural pest control by bats (Kunz et al., 2011; Medellin,

Wiederholt \& Lopez-Hoffman, 2017), provision of clean water (Griebler \& Avramov, 2015), serving as a source for new pharmaceutical products (Cheeptham et al., 2013), and even cheese production (Ozturkoglu-Budak et al., 2016). While services with direct benefit to humans have received some attention, values provided by subterranean ecosystems extend far beyond direct human needs. In light of emerging conservation issues associated with subterranean ecosystems (Mammola et al., 2019b), investigating ecological services and links between above- and belowground diversity in ecosystem functioning is crucial.

Two questions called for more research into life-history characteristics (e.g. growth rates, age and size at sexual maturity, longevity, and survival rates; Q25) and food-web specificities of subterranean communities (Q23). Interactions among life-history traits determine the fitness of each population, while interactions between populations and the environment dictate the distribution of species (Steranrs, 1992). Only a few studies have described life histories of subterranean species, and this is partially explained by the challenges of captive breeding and the technical problems and effort necessary to conduct in situ comprehensive studies (Vonk \& Nijman, 2006; Voituron et al., 2011; Venarsky, Huryn \& Benstead, 2012; Riesch et al., 2016; 
Simon et al., 2017). Consequently, the lack of knowledge on cave species traits limits our understanding of evolutionary and ecological processes occurring in subterranean ecosystems. Energy limitation is considered a primary mechanism influencing both evolutionary and ecological processes in subterranean environments (Venarsky \& Huntsman, 2018). However, a more nuanced understanding of subterranean food-web dynamics (Q23) will require other research actions, including to (i) understand the spatial and temporal dynamics of energy resources; (ii) compare resource quality with consumers' physiological requirements; and (iii) compare consumption rates with resource availability in subterranean habitats with different environmental conditions (e.g. terrestrial versus aquatic, fresh versus salt water, and detrital versus chemolithoautotrophic food webs).

Finally, understanding the role of stochastic events in caves was highlighted as a deficient area in community ecology (Q24). Given that these events are increasing in frequency amid the environmental crisis of the new millennium (Rahmstorf \& Coumou, 2011), the study of stochastic phenomena has emerged as a central topic in ecology (Scheffer et al., 2001). Recent papers used groundwater crustaceans to elucidate some of the mechanisms by which earthquakes affect the composition and structure of biological communities (Galassi et al., 2014; Fattorini et al., 2017; Fattorini, Di Lorenzo \& Galassi, 2018; Morimura et al., 2020). Additional studies have focused on the effect of other events, such as heavy precipitation (Calderón-Gutiérrez, SánchezOrtiz \& Huato-Soberanis, 2018) and flooding (Pacioglu et al., 2019). Although it may seem counterintuitive to study stochastic environmental shifts in caves, as they have been traditionally perceived as stable ecosystems, these examples show how caves may represent promising model systems for quantifying the impacts of abrupt environmental shifts driving ecosystem evolution (Mammola, 2019). 


\section{MACROECOLOGY AND BIOGEOGRAPHY}

523 Q26 - What drives subterranean patterns of phylogenetic and functional diversity? [\#21; 75\%]

524 Q27 - Would the use of novel molecular methods (e.g. metabarcoding, environmental DNA)

525 provide new insights on subterranean biodiversity patterns and affect known patterns? [\#27;

$52672 \%]$

527 Q28 - What is the species richness pattern of subterranean organisms globally? [\#31; 72\%]

528 Q29 - What factors drive the relative importance of speciation, extinction, and dispersal in

529 shaping subterranean diversity patterns across regions? [\#34; 71\%]

530 Q30 - Are current subterranean biodiversity patterns best explained by history of colonization of

531 surface ancestors or by in situ speciation and dispersal in subterranean habitats? [\#39; 70\%]

532 Q31 - How can sampling effort be standardized so that comparisons of species richness are 533 unbiased? [\#43; 69\%]

Over the last 20 years, research in subterranean ecology is shifting from local to landscape studies aiming to document and understand biodiversity patterns at regional to global scales

537 (Zagmajster et al., 2019). This transition is not without difficulties, as it requires linking biodiversity patterns to eco-evolutionary processes with little to no possibility for manipulative experiments. Six questions in 'Macroecology and biogeography' were identified in the top-50 list (Fig. 1). These questions mirror the main challenges faced when documenting and understanding broad-scale biodiversity patterns at the surface. The first challenge is assembling

542 the data required to bring out the characteristic features of biodiversity patterns at such broad

543 scales, while ensuring these patterns are not biased by sampling effort (Q28, Q31). Secondly, to

544 combine multiple sampling techniques, species identification methods (e.g. morphological and 
DNA-based identification), and biodiversity metrics (e.g. alpha, beta, and gamma diversity) in a

546

547

548

549

550

551

552

553

554

555

556

557

558

559

560

561

562

563

564

565

566

567

meaningful way to elucidate the many facets of biodiversity patterns (e.g. taxonomic,

phylogenetic, and/or functional diversity; Jarzyna \& Jetz, 2016) (Q27, Q26). Lastly, the relative contributions of different evolutionary processes (Q29) and diversification hypotheses (Q30) in shaping biodiversity patterns should be fully examined.

The publication of global subterranean diversity maps and databases is a recent phenomenon (Culver \& Pipan, 2019; Zagmajster et al., 2019). While diversity maps are informative as they portray differences in species richness among regions or countries, we still lack global maps showing species richness for spatial units of equal area [but see Zagmajster, Culver \& Sket (2008), Niemiller \& Zigler (2013), and Eme et al. (2015) for examples of regional- and continental-scale diversity maps]. Several approaches have been developed to minimize differences in species richness due to sampling bias (Q31). This issue is particularly germane to difficulties in sampling subterranean habitats. For example, sampling protocols were typically standardized among sites and completeness of species inventories were assessed using accumulation and rarefaction curves (Zagmajster et al., 2008; Dole-Olivier et al., 2009; Wynne et al., 2018). Also, observed species richness patterns were tested for robustness using species richness estimators (Zagmajster et al., 2014), or complemented with species richness predictions modelled from environmental data (Mokany et al., 2019).

Beyond accounting for sampling biases, molecular methods are increasingly useful in understanding subterranean biodiversity patterns (Q27). For example, a recent study comparing latitudinal patterns of crustacean species range size obtained from morphology- and DNA-based species delimitation showed that the pattern of increasing median range size at higher latitudes was more evident when delimiting species with DNA (Eme et al., 2018) (Fig. 2). As sequencing 
568 becomes increasingly applied to subterranean taxa, environmental DNA sampling and

569 monitoring may be also used to detect these species in areas difficult to access (Gorički et al.,

570 2017; Niemiller et al., 2018), thus resulting in more accurate maps of their distributions. To our

571 knowledge, patterns of phylogenetic and functional diversity at continental to global scales have

572 not been documented for any subterranean taxon (Q26), despite the growing knowledge of

573 phylogenetic relationships and species traits (Morvan et al., 2013; Fernandes, Batalha \&

574 Bichuette, 2016; Fišer et al., 2019; Mammola et al., 2020). Documenting these patterns will

575 further underscore the relative importance of dispersal, extinction, and different speciation

576 modes in shaping geographic variation of species richness. Given the differences in global

577 diversity patterns between subterranean and surface habitats, comparing the two systems might

578 help further to elucidate the key drivers of diversity.

579 Recent macroecological studies have shown that historical climatic variability, spatial

580 heterogeneity, and energy contribute to species richness patterns of subterranean taxa in Europe.

581 However, the contributions of these factors vary regionally and across taxa (Eme et al., 2015;

582 Bregović \& Zagmajster, 2016; Bregović, Fišer \& Zagmajster, 2019; Mammola et al., 2019a). At

583 a landscape scale, linking environmental factors with speciation, extinction, and dispersal

584 dynamics (Q29), as well as diversification processes (Q30), remains challenging and requires the

585 use of phylogenetic methods and a large number of specimens for DNA analysis (Stern et al.,

586 2017). Yet phylogenetic methods encompass uncertainties that are highly sensitive to sampling

587 bias and the confounding effect of extinction, both obscuring the inference of transitions to

588 subterranean life. To ameliorate this, genes that lose their function soon after the transition

589 should be used (Lefébure et al., 2017) (see also Section V).

590 
591

592

593

594

595

596

597

598

599

600

601

602

603

604

605

606

607

608

609

610

611

612

613

\section{CONSERVATION}

Q32 - How does climate change affect subterranean-adapted organisms? [\#2; 84\%]

Q33 - What are the effects of pollution on subterranean-restricted microorganisms, arthropods, and vertebrates? [\#3; 84\%]

Q34 - What is the impact of above-ground disturbance on subterranean environments and their

fauna? [\#5; 82\%]

Q35 - How can we evaluate the ecological status of subterranean ecosystems? [\#6; 80\%]

Q36 - How can we protect subterranean-adapted species from invasive species? [\#7; 80\%]

Q37 - How can we combine policy, education, research, and management to safeguard

subterranean biodiversity effectively? [\#8; 80\%]

Q38* - What factors determine the size and location of effective protected areas in subterranean

environments? [\#10; 78\%]

Q39* - How can we effectively involve governments and key stakeholders in the conservation of

caves and other subterranean systems? [\#17; 75\%]

Q40 - What would be the best monitoring protocols to quantify long-term changes in the distribution and abundance of subterranean invertebrates? [\#18; 75\%]

Q41 - How do we address the lack of knowledge (biodiversity shortfalls) about the biology of subterranean species to enhance proper conservation measures? [\#25; 73\%]

Q42 - Can subterranean-adapted organisms be used as bioindicators of the health of subterranean ecosystems? [\#45; 69\%]

Q43 - How does the use of caves by humans (e.g. tourism, religious, therapeutic, and recreational activities) affect subterranean ecosystems? [\#48; 68\%] 
614 Ecosystems are experiencing biodiversity loss at an unprecedented rate worldwide (Barnosky et 615 al., 2011; Dirzo et al., 2014; IPBES, 2018; Cardoso et al., 2020). Thus, conservation and 616 management of cave biological diversity is of the utmost concern among subterranean biologists 617 (Mammola et al., 2019b). Conservation questions comprised most of the questions (24\%) in our 618 top-50 list (Fig. 1). Of these, 10 questions were part of the initial List \#1, while two additional 619 questions were suggested by survey participants. Three questions (Q32, Q33, and Q36) 620 highlighted three of the greatest threats to biodiversity worldwide - climate change (Ripple et al., 621 2019), pollution (Ripple et al., 2017), and invasive alien species (Pyšek et al., 2020) - whose 622 effects are pervasive also underground (Mammola et al., 2019b). Additional questions were 623 centred on the impacts of above-ground disturbance (Q34) and human activities (Q43) on 624 subterranean habitats. All these threats can be combined and described as 'habitat loss and 625 degradation', which is one of the most important drivers of biodiversity loss globally (IPBES, 626 2018). Subterranean habitat loss and degradation is primarily due to surface activities, such as 627 agricultural expansion and intensification, urbanization, and mining activities (Reboleira et al., 628 2013; Mammola et al., 2019b; Castaño-Sánchez, Hose \& Reboleira, 2020). Human activities 629 inside caves may also constitute localized threats, with recreational use and tourism activities 630 being of particular concern (Fernandez-Cortes et al., 2011; Faille, Bourdeau \& Deharveng, 631 2015). In certain areas, people are even poaching rare invertebrate species for private collections 632 (Simičević, 2017), as in the discussed case of Anophthalmus hitleri Scheibel (Coleoptera: 633 Carabidae) (Berenbaum, 2010).

634 Evaluating, understanding, and mitigating these threats are primarily hampered by our 635 scarce knowledge of subterranean organisms' biology (Q41), especially life-history traits (see 636 Q25 in Section VI). Understanding changes in species' abundance and distribution will be 
637 crucial to halting biodiversity loss in subterranean habitats. Studies aimed at identifying

638 bioindicator species (Q42) to help bolster long-term monitoring programs (Q40) are needed.

639 Additionally, improved sampling procedures and characterizing cave communities in previously

640 undocumented areas would both enhance our knowledge of subterranean biodiversity (Mammola

641 et al., 2019b) and improve the effectiveness of conservation measures (Q41).

642 Furthermore, it is crucial to adopt innovative approaches to safeguard subterranean

643 biodiversity (Q37), as well as to determine the size and location of effective protected areas

644 (Q38). Standardized systematic sampling techniques have been applied to terrestrial (Wynne et

$645 a l ., 2018,2019$ ) and aquatic subterranean invertebrate species (Dole-Olivier et al., 2009); to be

646 optimally beneficial to conservation and monitoring, these techniques will need to be further

647 scrutinized across a large breadth of taxa and systems. Recently, a cave vulnerability assessment

648 protocol has been developed for bat cave roosts (Tanalgo, Tabora \& Hughes, 2018) and, if

649 refined, would hold promise for use with other subterranean animals.

650 Protected areas are the most crucial measure to safeguard specific subterranean habitats

651 and the sensitive animal populations they often support (Q38). Indices have been developed for

652 site selection and conservation prioritization (e.g. Borges et al., 2012; Rabelo, Souza-Silva \&

653 Ferreira, 2018; Strona et al., 2019; Fattorini et al., 2020) which are often based on

654 complementarity, flexibility, and irreplaceability principles (Michel et al., 2009). Yet, rigorous

655 geospatial analysis is still rarely applied when the extents of protected areas are being

656 determined. Further considerations should include managing lands upslope from caves or entire

657 watersheds supporting sensitive subterranean habitats. If a species-level approach is taken for

658 establishing a protected area, it would be reasonable to protect the land at the hydrogeologic unit

659 (i.e. watershed or karst/volcanic unit) level - as animals are expected to use mesocaverns or 
660

661

662

663

664

665

666

667

668

669

670

671

672

673

674

675

676

677

678

679

680

681

682

unconsolidated sediments for dispersal (Howarth, 1983; Malard et al., 2017; Trontelj, 2019).

Importantly, such an approach should be based on the most accurate estimation of the relevant animal's distributional range.

While effective legislation and/or management plans exist for some subterranean species and some regions of the world, overall management policies for most regions of speleological importance are lacking (Q39). Only a few countries have national cave protection laws. For example, the United States Federal Cave Protection Act of 1988 has been used as a tool to manage caves on federally owned lands, while Brazil requires geological and biological assessments of caves and stipulates mitigation of any human activities that may negatively impact cave natural resources. In any case, to be fully operational, such legislative and management tools need to be based on the best available science including a comprehensive knowledge of fauna distribution (Brooks, Da Fonseca \& Rodrigues, 2004; Samways et al., 2020) and traits of the species of concern (Chichorro, Juslén \& Cardoso, 2019; Fattorini et al., 2020). Importantly, management plans will require both financial, governmental, and local community support for their implementation. Unfortunately, most countries lack the capacity or legislation to protect and conserve sensitive subterranean resources.

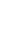

\section{MICROBIOLOGY AND APPLIED TOPICS}

Q44 - What is the role of Bacteria, Archaea, fungi, and viruses in nutrient cycling in subterranean systems? [\#32; 71\%]

Q45 - How adaptable are cave microorganisms to changing environmental conditions (e.g. climate change)? [\#37; 70\%]

Q46 - How do other organisms (humans and other animals), and their activities (e.g. visiting 
683 humans and global climate change) influence cave microbiome diversity patterns? [\#38; 70\%]

684 Q47 - How does the range of energy sources and quantity influence the diversity of subterranean 685 microbiota? [\#46; 68\%]

686 Q48 - What are the limiting nutrients for subterranean microbiota and how do they affect overall 687 subterranean microbial diversity? [\#47; 68\%]

688 Q49 - How do subterranean microorganisms cycle key elements - nitrogen, iron, carbon, sulfur, 689 and phosphorus? [\#49; 67\%]

690 Q50* - What is the role of microorganisms in cave-formation processes (speleogenesis) in 691 subterranean environments? [\#50; 67\%]

692

693 Without a doubt, topics such as adaptation, origin and evolution, community dynamics, and 694 biogeographic distribution patterns are similarly important and actively targeted in microbial 695 ecology (Antwis et al., 2017). However, research in macroecology and microbial ecology is 696 often conducted separately rather than hand-in-hand. For nearly 200 years, subterranean 697 ecosystems have been studied from a macroscopic perspective. Subterranean microbiological 698 research is a relatively new discipline with most research having been conducted since the 699 middle of the last century (Griebler \& Lueders, 2009). A modern ecosystem approach to

700 subterranean biota requires consideration across all trophic levels and scales (Hershey \& Barton, 701 2019), especially since the 1980s, when the first cave ecosystems fully sustained by in situ 702 chemosynthetic primary production were discovered (Sarbu, Kane \& Kinkle, 1996; Kumaresan 703 et al., 2014). The seven questions on the top-50 list address general problems that have been frequently 705 examined for various subterranean ecosystems, such as alluvial aquifers, however, less 
systematically for cave environments. Three questions focused on the active role of microorganisms in nutrient cycling $(\mathrm{Q} 44, \mathrm{Q} 49)$ and how nutrient limitations influence microbial diversity (Q48). Although we know that microbes rule the subsurface in terms of element cycles (Ortiz et al., 2014; Kimble et al., 2018) and constitute the basis of the food web, we still lack detailed information on conversion rates and growth kinetics. In addition, subterranean organisms often persist with limited energy resources. Thus, understanding their specific adaptations would help advance our understanding of adaptive strategies for microorganisms in other ecosystems (e.g. mountain-summit and deep-sea habitats). Additionally, the role of viruses, which only recently has been recognized as 'tremendous' for groundwater ecosystems (Griebler, Malard \& Lefébure, 2014), has not been investigated for terrestrial subterranean systems (Q44). Two questions further addressed the resistance and resilience of cave microbial communities to disturbance from changes in environmental conditions (Q45) (Cavicchioli et al., 2019), and the impacts of other organisms (in particular, humans; Moldovan et al., 2020; Martínez et al., 2020) on microbial diversity (Q46). These questions also were related to conservation issues from a microbiological perspective. The adverse impacts of the fungus Pseudogymnoascus destructans that causes white-nose syndrome in North American bats is a prominent example. To date, $P$. destructans occurs in 38 U.S. states and seven Canadian provinces (see http://www.whitenosesyndrome.org), which raises serious concerns for the conservation of hibernating bat species and the ecosystem services they provide (Kunz et al., 2011; Boyles et al., 2011; Medellin et al., 2017; Mammola et al., 2019b). The fungus is an opportunistic environmental pathogen, which can remain in the subterranean environment and contribute to the cave microbiome even in the absence of its host (Lorch et al., 2013). 
redundancy do not select for ecosystems poor in energy and stable in environmental conditions (Griebler \& Lueders, 2009). Thus, the introduction of novel species may have a destabilizing effect on a cave's biological equilibrium (Q46). The same is true for the introduction of contaminants, such as organic compounds and nutrients that provide additional energy. We are only beginning to understand whether and how energy-diversity relationships known from macroecology apply to complex natural bacterial communities (Q47). In fact, there is a growing body of evidence that diversity-productivity relationships also drive microbial communities (Smith, 2007), but this question has not been examined systematically in subterranean ecosystems yet.

Finally, Q50 points to the potential contribution of microorganisms in speleogenetic processes, such as weathering and rock formation via inducing precipitation. Specifically, in terms of (inorganic) carbon cycling in face of climate change, the role of microbes in the formation of caves may be of great relevance, and has yet to be fully examined.

\section{CONCLUSIONS}

(1) The 50th anniversary of Poulson \& White's (1969) article was the perfect time to reflect on milestone scientific achievements obtained in the natural laboratories offered by caves, while also delineating the most important research priorities for years to come. We have shown how subterranean biology has contributed strongly to general scientific questions via the study of evolutionary and ecological processes along the vertical dimension (i.e. the evolutionary transition from the surface to the subsurface). These accomplishments resonate with the sentiments of Poulson \& White (1969) and we anticipate that biologists will continue to unravel the mysteries of subterranean ecosystems and contribute to scientific knowledge more broadly, 
752 insofar as revolutionary advances in approaches and technologies continue to foster and nurture 753 novel paradigms.

754 (2) There is a significant lack of knowledge concerning eco-evolutionary processes underlying 755 biodiversity patterns along the horizontal gradient (i.e. within subterranean habitats). This is 756 largely driven by a paucity of functional ecology studies, the weakness of trait-based approaches

757 (Cardoso, 2012; Fernandes et al., 2016; Fišer et al., 2019; Mammola et al., 2020), and the lack of 758 robust systematic sampling techniques for most taxonomic groups (Wynne et al., 2019).

759 Bridging these gaps will significantly influence how we address and prioritize future research on 760 the conservation and ecosystem services of subterranean habitats (e.g. Fattorini et al., 2020), as 761 emphasized by the large number of unresolved questions in conservation biology (representing 762 nearly $25 \%$ of the top-50 list).

763 (3) We also invite scientists to redouble their efforts to understand the diversity of subterranean 764 life across all its components, with a special focus on linking macroscopic and microbial ecology 765 (Foulquier et al., 2011; Mermillod-Blondin, 2011). This will enable us to achieve a mechanistic

766

767

768

769

770

771

772

773 774 understanding of subterranean eco-evolutionary processes and ecosystem function. This information will be critical in guiding future policy decisions as human activities and global environmental change increasingly impact and strain the subterranean realm.

(4) There is a concern that simple voting exercises such as this one may favour general over specific questions. Perhaps as a result of this bias, some of the top-voted questions appear to be broad in scope (e.g. Q1, Q2, and Q32). While these questions were able to capture important general lines of inquiry, specific questions may be more useful for setting applied agendas. Therefore, we invite interested readers to consult Appendix S1, which contains our complete list of 120 questions. 
775 (5) While the 'caves as laboratory' paradigm is an effective way to frame broadly scoped studies,

776 we recognize the top-50 list of questions primarily pertains to unresolved issues within the

777 borders of subterranean biology. Yet subterranean habitats offer much more. Deep subterranean

778 habitats are one of the few natural systems defined by highly stable and homogenous climatic

779 conditions tantamount to those maintained in a laboratory (Sánchez-Fernández et al., 2018).

780 These systems have an island-like nature (Itescu, 2019), and often support communities

781 characterized by highly specialized organisms interacting in simplified ecological networks

782 (Mammola, 2019). By extension, a robust understanding of these rather simplified settings may

783 enable researchers to disentangle the complexities of more diverse systems (e.g. deep-sea

784 habitats).

785 (6) Ultimately, all these features point at subterranean ecosystems as ideal settings in which to

786 tackle general questions. We strived to provide examples of how some of our survey questions

787 may aid in addressing non-cave specific agendas. Our hope is that this horizon scan exercise both

788 underscores the importance of caves for addressing a range of eco-evolutionary questions, as

789 well as stimulates researchers to redouble their efforts to address some of these lingering

790 questions in subterranean biology.

791

792 XI. ACKNOWLEDGEMENTS

793 A special thanks to our colleagues around the world who participated in the online survey and

794 made this paper possible. Thanks to Alison Cooper, Simone Fattorini and two anonymous

795 referees for useful suggestions through the review process. S.M. was supported by the CAWEB

796 project "Testing macroecological theory using simplified systems", funded by the European

797 Commission through Horizon 2020 Marie Skłodowska-Curie Actions (MSCA) individual 
798 799

800

801

802

803

804

805

806

807

808

809

810

811

812

813

814

815

816

817

818

819

820

fellowships (Grant no. 882221). I.R.A. was supported by Portuguese funds through FCT Fundação para a Ciência e a Tecnologia, I.P., under the Norma Transitória -

DL57/2016/CP1375/CT0003. D.E. was supported by IFREMER and by the CERES “Climate change and European Aquatic Resources" project funded by European Commission through Horizon 2020 research and innovation programme (Grant no. 678193). C.F., Z.F., and M.Z. were supported by the Slovenian Research Agency (program P1-0184, project N1-0069). J.E.K. was funded by NSF awards DEB1754231 and IOS1933428, and EDGE award 1923372. F.M. was supported by the French National Research Agency projects CONVERGENOMICS (ANR-15CE32-0005) and EUR H2O'Lyon (ANR-17-EURE-0018). A.M. was supported by the ANCAVE project "Anchialine caves to understand evolutionary processes", funded by the European Commission through Horizon 2020 Marie Skłodowska-Curie Actions (MSCA) individual fellowships (Grant no. 745530). P.A.V.B. was supported by the project AZORESBIOPORTAL PORBIOTA (ACORES-01-0145-FEDER-000072), financed by FEDER in 85\% and by Azorean Public funds by $15 \%$ through Operational Program Azores 2020. A.S.P.S.R. was supported by VILLUM FONDEN (Grant no. 15471) and by a Carlsbergfondet grant (CF19-0609). T.G.P. was supported by Vale S.A. and Fundação de Amparo à Pesquisa de Minas Gerais (FAPEMIG) for individual fellowship (RDP 00092-18). T.P. was supported by the Karst Research Programme P6-0119, LifeWatch ERIC, RI-SI LifeWatch, and EU H2020 project eLTER.

Author contributions: S.M. and P.C. conceived the idea, coordinated the survey, and curated the lists of questions. T.P., S.J.B.C., R.L.F., F.M., P.A.V.B., T.M.L., and D.C.C. coordinated research panels to identify research questions. All authors except S.M. and P.C. assembled the initial list of questions (see Table 1 for details). All authors were involved in online voting, and contributed to manuscript writing. 


\section{REFERENCES}

823

ANTwis, R.E., Griffiths, S.M., Harrison, X.A., ARANEga-Bou, P., ARCE, A., Bettridge, A.S., Brailsford, F.L., De Menezes, A., Devaynes, A., Forbes, K.M., Fry, E.L., GoOdHEAD, I., HASKell, E., HEYS, C., JAMES, C., ET AL. (2017). Fifty important research questions in microbial ecology. FEMS Microbiology Ecology 93, 10.1093/femsec/fix044.

AUDRA, P. \& PALMER, A.N. (2011). The pattern of caves: controls of the epigenic speleogensis. Géomorphologie 17, 359-378.

Barnosky, A.D., Matzke, N., TOMiYa, S., Wogan, G.O.U., SwartZ, B., Quental, T.B., Marshall, C., McGuire, J.L., Lindsey, E.L., Maguire, K.C., Mersey, B. \& Ferrer, E.A. (2011). Has the Earth's sixth mass extinction already arrived? Nature 471, 51-57.

BARR, T.C. \& HolSINGER, J.R. (1985). Speciation in cave faunas. Annual Review of Ecology and Systematics 16, 313-337.

Berenbaum, M. (2010). ICE Breakers. American Entomologist 56, 132-185.

BILANDŽIJA, H., ĆETKOviĆ, H. \& JEFFERY, W.R. (2012). Evolution of albinism in cave planthoppers by a convergent defect in the first step of melanin biosynthesis. Evolution \& Development 14, 196-203.

BilandžIJA, H., Hollifield, B., Steck, M., Meng, G., NG, M., Koch, A.D., GraČAn, R., ĆetKović, H., Porter, M.L., Renner, K.J. \& JefFery, W. (2020). Phenotypic plasticity as a mechanism of cave colonization and adaptation. eLife $\mathbf{9}$, e51830.

BLOUNT, Z.D., LENSKI, R.E. \& LOSOS, J.B. (2018). Contingency and determinism in evolution: replaying life's tape. Science 362, eaam5979.

Borges, P.A.V., Cardoso, P., Amorim, I.R., Pereira, F., Constância, J.P., Nunes, J.C., 
Barcelos, P., Costa, P., Gabriel, R. \& Dapkevicius, M. DE L. (2012). Volcanic caves: priorities for conserving the Azorean endemic troglobiont species. International Journal of Speleology 41, 101-112.

847

Boulton, A.J. (2020). Conservation of groundwaters and their dependent ecosystems: integrating molecular taxonomy, systematic reserve planning and cultural values. Aquatic Conservation: Marine and Freshwater Ecosystems 30, 1-7.

Boyles, J.G., CRYAN, P.M., MCCRACKEN, G.F. \& KUNZ, T.H. (2011). Economic importance of bats in agriculture. Science 332, 41-42.

BREgović, P., FIŠER, C. \& ZAGMAJSTER, M. (2019). Contribution of rare and common species to subterranean species richness patterns. Ecology and Evolution 9, 11606-11618.

BREGOVIĆ, P. \& ZAGMAJSTER, M. (2016). Understanding hotspots within a global hotspot identifying the drivers of regional species richness patterns in terrestrial subterranean habitats. Insect Conservation and Diversity 9, 268-281.

Brooks, T., Da Fonseca, G.A.B. \& Rodrigues, A. (2004). Species, data, and conservation planning. Conservation Biology 18, 1682-1688.

BUHAY, J.E. \& CRANDALL, K.A. (2005). Subterranean phylogeography of freshwater crayfishes shows extensive gene flow and surprisingly large population sizes. Molecular Ecology 14, $4259-4273$.

Calderón-Gutiérrez, F., Sánchez-Ortiz, C.A. \& Huato-Soberanis, L. (2018). Ecological patterns in anchialine caves. PLOS ONE 13, e0202909.

CARDOSO, P. (2012). Diversity and community assembly patterns of epigean vs. troglobiont spiders in the Iberian Peninsula. International Journal of Speleology 41, 83-94. Cardoso, P., Barton, P.S., Birkhofer, K., Chichorro, F., Deacon, C., Fartmann, T., 

humanity on insect extinctions. Biological Conservation 242, 108426.

870 CARLINI, D.B. \& FONG, D.W. (2017). The transcriptomes of cave and surface populations of Gammarus minus (Crustacea: Amphipoda) provide evidence for positive selection on cave downregulated transcripts. PLOS ONE 12, e0186173.

Castaño-SÁnchez, A., Hose, G.C. \& Reboleira, A.S.P.S. (2020). Ecotoxicological effects of anthropogenic stressors in subterranean organisms: a review. Chemosphere 244, 125422.

CAVicchioli, R., RipPle, W.J., Timmis, K.N., AZAM, F., BAKKEN, L.R., BAYLis, M., Behrenfeld, M.J., Boetius, A., Boyd, P.W., Classen, A.T., Crowther, T.W., Danovaro, R., Foreman, C.M., Huisman, J., Hutchins, D.A., ET AL. (2019). Scientists’ warning to humanity: microorganisms and climate change. Nature Reviews Microbiology

Cheeptham, N., Sadoway, T., Rule, D., Watson, K., Moote, P., Soliman, L.C., Azad, N., DONKOR, K.K. \& HoRnE, D. (2013). Cure from the cave: volcanic cave actinomycetes and their potential in drug discovery. International Journal of Speleology 42, 35-47.

Chichorro, F., Juslén, A. \& CARdoso, P. (2019). A review of the relation between species traits and extinction risk. Biological Conservation 237, 220-229. reversible? Independent and recent large-scale dispersal into surface waters by two species of the groundwater amphipod genus Niphargus. Molecular Phylogenetics and Evolution

889 COURChAMP, F. \& BRADSHAw, C.J.A. (2018). 100 articles every ecologist should read. Nature 
Ecology \& Evolution 2, 395-401.

891

892

893

894

895

896

897

898

899

900

901

902

903

904

905

906

907

908

909

910

911

912

CUlver, D.C. (1970). Analysis of simple cave communities I. Caves as islands. Evolution 24, $463-474$.

CUlver, D.C. \& PIPAN, T. (2019). The biology of caves and other subterranean habitats. Oxford University Press, USA.

CuRL, L.R. (1964). On the definition of a cave. National Speleological Society Bullettin 26, 1-6.

DARWIN, C. (1859). On the origin of species by means of natural selection, or the preservation of favoured races in the struggle of life. John Murray, London.

DEHARVENG, L. \& BeDOS, A. (2019). Diversity of terrestrial invertebrates in subterranean habitats. In Cave Ecology (eds T. Moldovan, L. KovÁČ \& S. HALSE), pp. 107-172. Springer, Cham, Switzerland.

Dirzo, R., Young, H.S., Galetti, M., Ceballos, G., IsaAC, N.J.B. \& Collen, B. (2014). Defaunation in the Anthropocene. Science 345, 401-406.

Dole-Olivier, M.J., Castellarini, F., Coineau, N., Galassi, D.M.P., Martin, P., Mori, N., VALDECASAS, A. \& GiBERT, J. (2009). Towards an optimal sampling strategy to assess groundwater biodiversity: comparison across six European regions. Freshwater Biology 54, $777-796$.

Drummond, A.J., Ho, S.Y.W., PhilliPS, M.J. \& RAmbaut, A. (2006). Relaxed phylogenetics and dating with confidence. PLoS Biology 4, e88.

Eme, D., Zagmajster, M., Delić, T., FiŠER, C., Flot, J.-F., Konecny-DuprÉ, L., PÁlsson, S., Stoch, F., ZAKŠEK, V., DOUAdy, C.J. \& MALARD, F. (2018). Do cryptic species matter in macroecology? Sequencing European groundwater crustaceans yields smaller ranges but does not challenge biodiversity determinants. Ecography 41, 424-436. 
913 Eme, D., Zagmajster, M., Fišer, C., Galassi, D., Marmonier, P., Stoch, F., Cornu, J.F., 914 OBERDORFF, T. \& MALARD, F. (2015). Multi-causality and spatial non-stationarity in the 915 determinants of groundwater crustacean diversity in Europe. Ecography 38, 531-540.

916 Faille, A., Bourdeau, C. \& Deharveng, L. (2015). Weak impact of tourism activities on 917 biodiversity in a subterranean hotspot of endemism and its implications for the conservation 918 of cave fauna. Insect Conservation and Diversity 8, 205-215.

919 Faille, A., Ribera, I., Deharveng, L., Bourdeau, C., Garnery, L., Quéinnec, E. \& Deuve, 920 T. (2010). A molecular phylogeny shows the single origin of the Pyrenean subterranean 921 Trechini ground beetles (Coleoptera: Carabidae). Molecular Phylogenetics and Evolution $922 \quad \mathbf{5 4}, 97-106$.

923 Fattorini, S., Lombardo, P., Fiasca, B., Di Cioccio, A., Di Lorenzo, T. \& Galassi, D.M.P. 924 (2017). Earthquake-related changes in species spatial niche overlaps in spring communities. $925 \quad$ Scientific Reports 7, 443.

926 FATTORINI, S., Di LORENZO, T. \& GALASSI, D.M.P. (2018). Earthquake impacts on 927 microcrustacean communities inhabiting groundwater-fed springs alter species-abundance 928 distribution patterns. Scientific Reports 8, 1501.

929 FAtTorini, S., Fiasca, B., Di Lorenzo, T., Di CicCO, M. \& GAlassi, D.M.P. (2020). A new 930 protocol for assessing the conservation priority of groundwater-dependent ecosystems. 931 Aquatic Conservation: Marine and Freshwater Ecosystems, doi:10.1002/aqc.3411

932 Fernandes, C.S., Batalha, M.A. \& Bichuette, M.E. (2016). Does the cave environment 933 reduce functional diversity? PLOS ONE 11, e0151958.

934 Fernandez-Cortes, A., Cuezva, S., Sanchez-Moral, S., Cañaveras, J.C., Porca, E., 935 Jurado, V., MARTin-SAnChEZ, P.M. \& SAiz-JimenEZ, C. (2011). Detection of human- 

Research 18, 1037-1045.

FIRE, M. \& GUESTRIN, C. (2019). Over-optimization of academic publishing metrics: observing 939 Goodhart's Law in action. GigaScience 8, giz053.

940

941

942

943

944

945

946

947

948

949

950

951

952

953

954

955

956

957 958

FiŠER, C., Delić, T., LuŠTrik, R., ZAGMAjSTER, M. \& AltermatT, F. (2019). Niches within a niche: ecological differentiation of subterranean amphipods across Europe's interstitial waters. Ecography 42, 1212-1223.

FlôRES, D.E.F.L., Tomotani, B.M., TACHinARd, P., OdA, G.A. \& VAlentinuZZI, V.S. (2013). Modeling natural photic entrainment in a subterranean rodent (Ctenomys aff. knighti), the Tuco-Tuco. PLoS ONE 8, e68243.

Foulquier, A., Malard, F., Mermillod-Blondin, F., Montuelle, B., Dolédec, S., Volat, B. \& GIBERT, J. (2011). Surface water linkages regulate trophic interactions in a groundwater food web. Ecosystems 14, 1339-1353.

FRIEDRICH, M. (2013). Biological clocks and visual systems in cave-adapted animals at the dawn of Speleogenomics. Integrative and Comparative Biology 53, 50-67.

Fumey, J., Hinaux, H., Noirot, C., Thermes, C., RÉtauX, S. \& CaSane, D. (2018). Evidence for late Pleistocene origin of Astyanax mexicanus cavefish. BMC Evolutionary Biology 18, 43.

Galassi, D.M.P., Lombardo, P., Fiasca, B., Di Cioccio, A., Di Lorenzo, T., PetitTa, M. \& Di CARLO, P. (2014). Earthquakes trigger the loss of groundwater biodiversity. Scientific Reports 4, 6273.

GAtenby, R.A., Gillies, R.J. \& BROwn, J.S. (2011). Of cancer and cave fish. Nature Reviews Cancer 11, 237. 
959 Gibert, J. \& DEHARVENG, L. (2002). Subterranean ecosystems: a truncated functional 960 biodiversity. BioScience 52, 473-481.

961 Gillespie, R.G., Bennett, G.M., De MeEster, L., Feder, J.L., Fleischer, R.C., HARMON, L.J., 962 Hendry, A.P., Knope, M.L., Mallet, J., Martin, C., Parent, C.E., PAtton, A.H., 963 PfenNig, K.S., RubinOFF, D., Schluter, D., ET AL. (2020). Comparing adaptive radiations 964 across space, time, and taxa. Journal of Heredity 111, 1-20.

965 GoričKi, Š., Stankovic, D., Snoj, A., Kuntner, M., JefFery, W.R., Trontelu, P., Pavic, M., 966 Grizelu, Z., NAPARUS-AlJANCIC, M. \& AlJANCIC, G. (2017). Environmental DNA in 967 subterranean biology: Range extension and taxonomic implications for Proteus. Scientific $968 \quad$ Reports 7, 91-93.

969 Gould, S.J. \& VRBA, E.S. (1982). Exaptation - a missing term in the science of form. $970 \quad$ Paleobiology 8, 4-15.

971 Griebler, C. \& AvrAmov, M. (2015). Groundwater ecosystem services: a review. Freshwater $972 \quad$ Science 34, 355-367.

973 GrIEBLER, C. \& LUEDERS, T. (2009). Microbial biodiversity in groundwater ecosystems. $974 \quad$ Freshwater Biology 54, 649-677.

975 Griebler, C., Malard, F. \& LefÉbure, T. (2014). Current developments in groundwater 976 ecology-from biodiversity to ecosystem function and services. Current Opinion in 977 Biotechnology 27, 159-167.

978 GuziK, M.T., CoOper, S.J.B., Humphreys, W.F. \& Austin, A.D. (2009). Fine-scale 979 comparative phylogeography of a sympatric sister species triplet of subterranean diving 980 beetles from a single calcrete aquifer in Western Australia. Molecular Ecology 18, 3683$981 \quad 3698$. 
982 Hershey, O.S. \& BARTON, H.A. (2019). The microbial diversity of caves. In Cave Ecology (eds

983 T. Moldovan, L. KovÁČ \& S. HalSE), pp. 69-90. Springer, Cham, Switzerland.

984 HOWARTH, F.G. (1982). Bioclimatic and geologic factors governing the evolution and

985 distribution of Hawaiian cave insects. Entomologia Generalis 8, 17-26.

986 HowARTH, F.G. (1983). Ecology of cave arthropods. Annual Review of Entomology 28, 365-389.

987 Howarth, F.G., James, S.A., McDowell, W., Preston, D.J. \& ImadA, C.T. (2007).

988 Identification of roots in lava tube caves using molecular techniques: implications for

989 conservation of cave arthropod faunas. Journal of Insect Conservation 11, 251-261.

990 Hyacinthe, C., AtTiA, J. \& RÉTAuX, S. (2019). Evolution of acoustic communication in blind

$991 \quad$ cavefish. Nature Communications 10, 4231.

992 IOANNIDIS, J.P.A. (2005). Why most published research findings are false. PLOS Medicine 2, 993 e124.

994

995

996

997

998

999

1000

1001

1002

1003

1004

IPBES (2018). Summary for policymakers of the thematic assessment report on land degradation and restoration of the Intergovernmental Science-Policy Platform on Biodiversity and Ecosystem Services. Preliminary guide regarding diverse conceptualization of multiple values of nature and its benefits, including biodiversity and ecosystem functions and services (deliverable $3(d)$ ).

ITESCU, Y. (2019). Are island-like systems biologically similar to islands? A review of the evidence. Ecography 42, 1298-1314.

Jarić, I., Correia, R.A., Brook, B.W., Buettel, J.C., Courchamp, F., Di Minin, E., Firth, J.A., Gaston, K.J., Jepson, P., Kalinkat, G., Ladle, R., Soriano-Redondo, A., Souza, A.T. \& RoLL, U. (2020). iEcology: harnessing large online resources to generate ecological insights. Trends in Ecology \& Evolution 35, 630-639. 
JARZYNA, M.A. \& JETZ, W. (2016). Detecting the multiple facets of biodiversity. Trends in Ecology \& Evolution 31, 527-538.

JEFFERY, W.R. (2005). Adaptive evolution of eye degeneration in the Mexican blind cavefish. Journal of Heredity 96, 185-196.

JEFFERY, W.R. (2009). Regressive evolution in Astyanax cavefish. Annual Review of Genetics $43,25-47$.

JeSCHKE, J.M., LOKATIS, S., BARTRAM, I. \& TOCKNER, K. (2019). Knowledge in the dark: scientific challenges and ways forward. FACETS 4, 423-441.

JINHA, A.E. (2010). Article 50 million: an estimate of the number of scholarly articles in existence. Learned Publishing 23, 258-263.

Johnson, G.D., IDA, H., SAKaue, J., SADO, T., Asahida, T. \& MiYa, M. (2012). A 'living fossil’ eel (Anguilliformes: Protanguillidae, fam. nov.) from an undersea cave in Palau. Proceedings of the Royal Society B: Biological Sciences 279, 934-943.

JoNES, K.K., COOPER, S.J.B. \& SEYMOUR, R.S. (2019). Cutaneous respiration by diving beetles from underground aquifers of Western Australia (Coleoptera: Dytiscidae). Journal of Experimental Biology 222, jeb196659.

JuAn, C., GuZIK, M.T., JAume, D. \& COOPER, S.J.B. (2010). Evolution in caves: Darwin's 'wrecks of ancient life' in the molecular era. Molecular Ecology 19, 3865-3880.

Khodami, S., McArthur, J.V., Blanco-Bercial, L. \& Martinez Arbizu, P. (2017). Molecular phylogeny and revision of copepod Orders (Crustacea: Copepoda). Scientific Reports 7, 9164.

Kimble, J.C., Winter, A.S., SPILDE, M.N., Sinsabaugh, R.L. \& NorthuP, D.E. (2018). A potential central role of Thaumarchaeota in $\mathrm{N}$-Cycling in a semi-arid environment, Fort 
Konec, M., PrevorČnik, S., SArbu, S.M., Verovnik, R. \& TrontelJ, P. (2015). Parallels between two geographically and ecologically disparate cave invasions by the same species, Asellus aquaticus (Isopoda, Crustacea). Journal of Evolutionary Biology 28, 864-875.

1032

1033

1034

1035

1036

1037

1038

1039

1040

1041

1042

1043

1044

1045

1046

1047

1048

1049

1050

Kumaresan, D., Wischer, D., Stephenson, J., Hillebrand-Voiculescu, A. \& MurRell, J.C. (2014). Microbiology of movile cave-A chemolithoautotrophic ecosystem.

Geomicrobiology Journal 31, 186-193.

Kunz, T.H., Braun de Torrez, E., Bauer, D., Lobova, T. \& Fleming, T.H. (2011). Ecosystem services provided by bats. Annals of the New York Academy of Sciences 1223, 1-38.

LANDHUIS, E. (2016). Scientific literature: information overload. Nature 535, 457-458.

Laurance, W.F., Useche, D.C., LAurance, S.G. \& Bradshaw, C.J.A. (2013). Predicting publication success for biologists. BioScience 63, 817-823.

Lefébure, T., Morvan, C., Malard, F., François, C., Konecny-Dupré, L., GuÉGuen, L., Weiss-Gayet, M., Seguin-Orlando, A., Ermini, L., SArkissian, C. Der, Pierre Charrier, N., Eme, D., Mermillod-Blondin, F., Duret, L., Vieira, C., ET AL. (2017). Less effective selection leads to larger genomes. Genome Research 27, 1016-1028.

LeiJs, R., van Nes, E.H., WATts, C.H., CoOper, S.J.B., Humphreys, W.F. \& Hogendoorn, K. (2012). Evolution of blind beetles in isolated aquifers: a test of alternative modes of speciation. PLOS ONE 7, e34260.

Lepore, E., Marchioro, A., Isaia, M., Buehler, M.J. \& Pugno, N.M. (2012). Evidence of the most stretchable egg sac silk stalk, of the European Spider of the Year Meta menardi. PLoS ONE 7, e30500.

Leys, R., COOPER, S.J.B., STRECKER, U. \& WiLKENS, H. (2005). Regressive evolution of an eye 
pigment gene in independently evolved eyeless subterranean diving beetles. Biology Letters

1052

1053

1054

1055

1056

1057

1058

1059

1060

1061

1062

1063

1064

1065

1066

1067

1068

1069

1070

1071

1072

1073

1, 496-499.

LEYS, R., WATTS, C.H.S., COOPER, S.J.B. \& HuMPHREYS, W.F. (2003). Evolution of subterranean diving beetles (Coleoptera: Dytiscidae: Hydroporini, Bidessini) in the arid zone of Australia. Evolution 57, 2819-2834.

LORCH, J.M., MulleR, L.K., Russell, R.E., O\&\#039;CONNOR, M., LindNER, D.L. \& BLEHERT, D.S. (2013). Distribution and environmental persistence of the causative agent of WhiteNose Syndrome, Geomyces destructans, in bat hibernacula of the Eastern United. Applied and Environmental Microbiology 79, 1293-1301.

Lozano-Fernandez, J., Giacomelli, M., Fleming, J.F., Chen, A., Vinther, J., Thomsen, P.F., Glenner, H., Palero, F., LegG, D.A., Iliffe, T.M., Pisani, D. \& Olesen, J. (2019). Pancrustacean evolution illuminated by taxon-rich genomic-scale sata sets with an expanded Remipede sampling. Genome Biology and Evolution 11, 2055-2070.

Lukić, M., Delić, T., PAVlek, M., Deharveng, L. \& ZagmajSTer, M. (2019). Distribution pattern and radiation of the European subterranean genus Verhoeffiella (Collembola, Entomobryidae). Zoologica Scripta 49, 86-100.

Malard, F., Capderrey, C., Churcheward, B., Eme, D., Kaufmann, B., Konecny-Dupré, L., LÉNA, J.-P., LIÉBAUlt, F. \& DOUADY, C.J. (2017). Geomorphic influence on intraspecific genetic differentiation and diversity along hyporheic corridors. Freshwater Biology 62, 1955-1970.

MAmmola, S. (2019). Finding answers in the dark: caves as models in ecology fifty years after Poulson and White. Ecography 42, 1331-1351.

Mammola, S. (2020). On deepest caves, extreme habitats, and ecological superlatives. Trends in 
Ecology \& Evolution 35, 469-472.

1075

1076

1077

1078

1079

1080

1081

1082

1083

1084

1085

1086

1087

1088

1089

1090

1091

1092

1093

1094

1095

1096

Mammola, S., ARnedo, M.A., Fišer, C., Cardoso, P., Dejanaz, A.J. \& IsaiA, M. (2020). Environmental filtering and convergent evolution determine the ecological specialization of subterranean spiders. Functional Ecology 34, 1064-1077.

Mammola, S., ARnedo, M.A., Pantini, P., Piano, E., Chiappetta, N. \& IsaiA, M. (2018).

Ecological speciation in darkness? Spatial niche partitioning in sibling subterranean spiders (Araneae : Linyphiidae : Troglohyphantes). Invertebrate Systematics 32, 1069-1082.

Mammola, S., Cardoso, P., Angyal, D., Balázs, G., Blick, T., Brustel, H., Carter, J., ĆurČIĆ, S., DANFlous, S., DÁNYi, L., DÉJEAN, S., DeltShev, C., Elverici, M., FERNÁNDEZ, J., GASPARO, F., ET AL. (2019a). Local- versus broad-scale environmental drivers of continental $\beta$-diversity patterns in subterranean spider communities across Europe. Proceedings of the Royal Society B: Biological Sciences 286, 20191579.

Mammola, S., Cardoso, P., Culver, D.C., Deharveng, L., Ferreira, R.L., Fišer, C., Galassi, D.M.P., Griebler, C., Halse, S., HumPhreys, W.F., Isaia, M., Malard, F., MartineZ, A., Moldovan, O.T., Niemiller, M.L., ET AL. (2019b). Scientists' warning on the conservation of subterranean ecosystems. BioScience 69, 641-650.

Mammola, S. \& LeROY, B. (2018). Applying species distribution models to caves and other subterranean habitats. Ecography 41, 1194-1208.

Mammola, S., Piano, E., Cardoso, P., Vernon, P., Domínguez-Villar, D., Culver, D.C., PIPAN, T. \& ISAIA, M. (2019c). Climate change going deep: the effects of global climatic alterations on cave ecosystems. The Anthropocene Review 6, 2053019619851594.

Mammola, S., Piano, E., Malard, F., Vernon, P. \& Isaia, M. (2019d). Extending Janzen's hypothesis to temperate regions: a test using subterranean ecosystems. Functional Ecology 
33, $1638-1650$.

Martínez, A., Di Cesare, A., Mari-Mena, N., García-Gómez, G., Garcia-Herrero, A., Corno, G., Fontaneto, D. \& ECKERT, E.M. (2020). Tossed 'good luck' coins as vectors for anthropogenic pollution into aquatic environment. Environmental Pollution 259, 113800.

MARtíneZ, A., KvindebJerg, K., IllFFe, T.M. \& WorsaAe, K. (2017). Evolution of cave suspension feeding in Protodrilidae (Annelida). Zoologica Scripta 46, 214-226.

McGill, B.J., Chase, J.M., Hortal, J., Overcast, I., Rominger, A.J., Rosindell, J., Borges, P.A. V, EMERSON, B.C., ETIENNE, R.S., Hickerson, M.J., MAHLER, D.L., MAssol, F., McGaughran, A., Neves, P., PArent, C., ET AL. (2019). Unifying macroecology and macroevolution to answer fundamental questions about biodiversity. Global Ecology and Biogeography 28, 1925-1936.

MEDEllin, R.A., WiEderholt, R. \& LopeZ-HofFMAN, L. (2017). Conservation relevance of bat caves for biodiversity and ecosystem services. Biological Conservation 211, 45-50.

MERMILlOD-BlONDIN, F. (2011). The functional significance of bioturbation and biodeposition on biogeochemical processes at the water-sediment interface in freshwater and marine ecosystems. Journal of the North American Benthological Society 30, 770-778.

Michel, G., Malard, F., Deharveng, L., Di Lorenzo, T., Sket, B. \& De Broyer, C. (2009). Reserve selection for conserving groundwater biodiversity. Freshwater Biology 54, 861876.

MokAny, K., Harwood, T.D., HALSE, S.A. \& FerRIER, S. (2019). Riddles in the dark: Assessing diversity patterns for cryptic subterranean fauna of the Pilbara. Diversity and Distributions 25, 240-254. 
Moldovan, O.T., Bercea, S., Năstase-Bucur, R., Constantin, S., Kenesz, M., Mirea, I.C., PetCulescu, A., RobU, M. \& ARGHIR, R.A. (2020). Management of water bodies in show caves - A microbial approach. Tourism Management 78, 104037.

Morimura, S., Zeng, X., Noboru, N. \& Hosono, T. (2020). Changes to the microbial communities within groundwater in response to a large crustal earthquake in Kumamoto, southern Japan. Journal of Hydrology 581, 124341.

Morvan, C., Malard, F., Paradis, E., Lefébure, T., Konecny-Dupré, L. \& Douady, C.J. (2013). Timetree of aselloidea reveals species diversification dynamics in groundwater. Systematic Biology 62, 512-522.

NiEMILLER, M.L., FitZPATRICK, B.M. \& MilLER, B.T. (2008). Recent divergence with gene flow in Tennessee cave salamanders (Plethodontidae: Gyrinophilus) inferred from gene genealogies. Molecular Ecology 17, 2258-2275.

NiemilLer, M.L., FitZPATRICK, B.M., Shah, P., SCHMitZ, L. \& NEAR, T.J. (2013). Evidence for repeated loss of selective constraint in rhodopsin of amblyopsid cavefishes (Teleostei: Amblyopsidae). Evolution 67, 732-748.

Niemiller, M.L., Porter, M.L., Keany, J., Gilbert, H., Fong, D.W., Culver, D.C., Hobson, C.S., KeNDALl, K.D., DAVIS, M.A. \& TAYLOR, S.J. (2018). Evaluation of eDNA for groundwater invertebrate detection and monitoring: a case study with endangered Stygobromus (Amphipoda: Crangonyctidae). Conservation Genetics Resources 10, 247257.

NiEMILLER, M.L. \& ZIGLER, K.S. (2013). Patterns of cave biodiversity and endemism in the 
Appalachians and Interior Plateau of Tennessee, USA. PLoS ONE 8, e64177.

1144

1145

1146

1147

1148

1149

1150

1151

1152

1153

1154

1155

1156

1157

1158

1159

1160

1161

1162

1163

1164

1165

Nuunjić, I., Perrard, A., Hendriks, K., Schilthuizen, M., Perreau, M., MerckX, V., BAYlaC, M. \& DEhaRveng, L. (2018). Comprehensive evolutionary analysis of the Anthroherpon radiation (Coleoptera, Leiodidae, Leptodirini). PLoS ONE 13, e0198367.

Northup, D.E., Melim, L.A., Spilde, M.N., Hathaway, J.J.M., GaRCiA, M.G., MoyA, M., Stone, F.D., Boston, P.J., DAPKevicius, M.L.N.E. \& RiQuelme, C. (2011). Lava cave microbial communities within mats and secondary mineral deposits: implications for life detection on other planets. Astrobiology 11, 601-618.

Ortiz, M., LegAtZKi, A., Neilson, J.W., Fryslie, B., Nelson, W.M., Wing, R.A., Soderlund, C.A., PRYOR, B.M. \& MAIER, R.M. (2014). Making a living while starving in the dark: metagenomic insights into the energy dynamics of a carbonate cave. ISME Journal 8, 478491.

Ozturkoglu-Budak, S., Gursoy, A., Aykas, D.P., KoÇAK, C., Dönmez, S., DE VRIES, R.P. \& BRON, P.A. (2016). Volatile compound profiling of Turkish Divle Cave cheese during production and ripening. Journal of Dairy Science 99, 5120-5131.

Pacioglu, O., Ianovici, N., Filimon, M., Sinitean, A., Iacob, G., Barabas, H., Pahomi, A., Acs, A., Muntean, H. \& PÂRvulescu, L. (2019). The multifaceted effects induced by floods on the macroinvertebrate communities inhabiting a sinking cave stream. International Journal of Speleology 48, 167-177.

PatiÑo, J., Whittaker, R.J., Borges, P.A. V, FernándeZ-Palacios, J.M., Ah-Peng, C., Araújo, M.B., Ávila, S.P., CARdoso, P., Cornuault, J., DE Boer, E.J., DE NASCimento, L., Gil, A., González-Castro, A., Gruner, D.S., Heleno, R., ET AL. (2017). A roadmap for island biology: 50 fundamental questions after 50 years of the Theory of Island 
Biogeography. Journal of Biogeography 44, 963-983.

1167 PECK, S.B. \& FinSTON, T.L. (1993). Galapagos islands troglobites: the questions of tropical troglobites, parapatric distributions with eyed-sister-species, and their origin by parapatric speciation. Memoires de Biospeologie 20, 19-37.

PÉREZ-MorenO, J.L., ILIFFE, T.M. \& BRACKEN-GRISSOM, H.D. (2016). Life in the Underworld: Anchialine cave biology in the era of speleogenomics. International Journal of Speleology 49, 149-170.

Plavén-Sigray, P., Matheson, G.J., Schiffler, B.C. \& ThOMPSON, W.H. (2017). The readability of scientific texts is decreasing over time. eLife $\mathbf{6}$, e27725.

Pons, J., Jurado-Rivera, J.A., JAume, D., Vonk, R., BAuZÀ-Ribot, M.M. \& JuAn, C. (2019). The age and diversification of metacrangonyctid subterranean amphipod crustaceans revisited. Molecular Phylogenetics and Evolution 140, 10659.

PoPA, R., SMith, A.R., POPA, R., BOONE, J. \& FISK, M. (2011). Olivine-respiring bacteria isolated from the rock-ice interface in a lava-tube cave, a mars analog environment. Astrobiology 12, 9-18.

PORTER, M.L. \& SuMnER-ROONEY, L. (2018). Evolution in the dark: unifying our understanding of eye loss. Integrative and Comparative Biology 58, 367-371.

Poulson, T.L. \& White, W.B. (1969). The cave environment. Science 165, 971-981.

PRENDINI, L., FRANCKE, O.F. \& VIGNOLI, V. (2010). Troglomorphism, trichobothriotaxy and typhlochactid phylogeny (Scorpiones, Chactoidea): more evidence that troglobitism is not an evolutionary dead-end. Cladistics 26, 117-142.

ProtAs, M. \& JEFFERY, W.R. (2012). Evolution and development in cave animals: from fish to crustaceans. Wiley interdisciplinary reviews. Developmental biology 1, 823-845. 
1189

1190

1191

1192

1193

1194

1195

1196

1197

1198

1199

1200

1201

1202

1203

1204

1205

1206

1207

1208

1209

1210

1211

PyŠEK, P., Hulme, P.E., Simberloff, D., BACher, S., Blackburn, T.M., CARlton, J.T.,

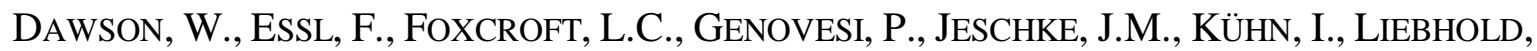
A.M., MANDRAK, N.E., MEYERSON, L.A., ET AL. (2020). Scientists' warning on invasive alien species. Biological Reviews, 10.1111/brv.12627

RABElo, L.M., SOUZA-Silva, M. \& FERREIRA, R.L. (2018). Priority caves for biodiversity conservation in a key karst area of Brazil: comparing the applicability of cave conservation indices. Biodiversity and Conservation 27, 2097-2129.

RAHMSTORF, S. \& COUMOU, D. (2011). Increase of extreme events in a warming world. Proceedings of the National Academy of Sciences 108, 17905-17909.

Reboleira, A.S.P.S., Abrantes, N., Oromí, P. \& Gonçalves, F. (2013). Acute toxicity of copper sulfate and potassium dichromate on stygobiont Proasellus: general aspects of groundwater ecotoxicology and future perspectives. Water, Air, \& Soil Pollution 224, 1550.

Riddle, M.R., Aspiras, A.C., Gaudenz, K., Peuß, R., Sung, J.Y., Martineau, B., Peavey, M., Box, A.C., Tabin, J.A., McGaugh, S., Borowsky, R., Tabin, C.J. \& Rohner, N. (2018). Insulin resistance in cavefish as an adaptation to a nutrient-limited environment. Nature $555,647$.

RIESCH, R., REZNICK, D.N., Plath, M. \& SCHLUPP, I. (2016). Sex-specific local life-history adaptation in surface- and cave-dwelling Atlantic mollies (Poecilia mexicana). Scientific Reports 6, 22968.

RipPle, W.J., Wolf, C., Newsome, T.M., Barnard, P. \& MoOmaW, W.R. (2019). World scientists' warning of a climate emergency. BioScience 70, 8-12.

RipPle, W.J., Wolf, C., Newsome, T.M., Galetti, M., Alamgir, M., Crist, E., Mahmoud, M.I., LAURANCE, W.F. \& 15364 SCIENTIST SIGNATORIES FROM 184 COUNTRIES (2017). 
World scientists' warning to humanity: a second notice. BioScience 67, 1026-1028.

1213

1214

1215

1216

1217

1218

1219

1220

1221

1222

1223

1224

1225

1226

1227

1228

1229

1230

1231

1232

1233

1234

SAmways, M.J., Barton, P.S., Birkhofer, K., Chichorro, F., Deacon, C., FARTMann, T., Fukushima, C.S., Gaigher, R., Habel, J.C., Hallmann, C.A., Hill, M.J., HochKirCh, A., KAILA, L., KwAK, M.L., MAES, D., ET AL. (2020). Solutions for humanity on how to conserve insects. Biological Conservation 242, 108427.

Sánchez-Fernández, D., Rizzo, V., Bourdeau, C., Cieslak, A., Comas, J., Faille, A., Fresneda, J., Lleopart, E., Millán, A., Montes, A., Pallares, S. \& Ribera, I. (2018). The deep subterranean environment as a potential model system in ecological, biogeographical and evolutionary research. Subterranean Biology 25, 1-7.

SARbU, S.M., KANE, T.C. \& KinKLE, B.K. (1996). A chemoautotrophically based cave ecosystem. Science 272, 1953-1955.

Scheffer, M., CARPenter, S., Foley, J.A., Folke, C. \& WAlKer, B. (2001). Catastrophic shifts in ecosystems. Nature 413, 591-596.

Seddon, A.W.R., Mackay, A.W., BAKer, A.G., Birks, H.J.B., Breman, E., Buck, C.E., Ellis, E.C., Froyd, C.A., Gill, J.L., Gillson, L., Johnson, E.A., Jones, V.J., JugGins, S., MACIAS-FAURIA, M., MiLls, K., ET AL. (2014). Looking forward through the past: identification of 50 priority research questions in palaeoecology. Journal of Ecology 102, $256-267$.

SIMIČEVIĆ, V. (2017). Poachers threaten Balkans underground biodiversity. Science 358, 1116 $\mathrm{LP}-1117$.

Simon, V., Elleboode, R., Mahé, K., Legendre, L., Ornelas-Garcia, P., EsPinasa, L. \& RÉTAUX, S. (2017). Comparing growth in surface and cave morphs of the species Astyanax mexicanus: insights from scales. EvoDevo 8, 23. 
SMITH, V.H. (2007). Microbial diversity-productivity relationships in aquatic ecosystems. FEMS Microbiology Ecology 62, 181-186.

SteRANRS, S. (1992). The Evolution of Life Histories. Oxford University Press, New York.

Stern, D.B., Breinholt, J., Pedraza-Lara, C., LóPez-Mejía, M., Owen, C.L., BrackenGrissom, H., FETZNER JR., J.W. \& CRANDALl, K.A. (2017). Phylogenetic evidence from freshwater crayfishes that cave adaptation is not an evolutionary dead-end. Evolution 71, $2522-2532$.

Strona, G., Fattorini, S., Fiasca, B., Di Lorenzo, T., Di Cicco, M., Lorenzetti, W., BOCCACCI, F. \& GALASSI, D.M.P. (2019). Aqualife software: a new tool for a standardized ecological assessment of groundwater dependent ecosystems. Water 11, 2574.

Sutherland, W.J., Dias, M.P., Dicks, L. V, Doran, H., Entwistle, A.C., Fleishman, E., Gibbons, D.W., Hails, R., Hughes, A.C., Hughes, J., Kelman, R., Le RouX, X., LeAnstey, B., Lickorish, F.A., MAGGS, L., ET AL. (2020). A horizon scan of emerging global biological conservation issues for 2020. Trends in Ecology \& Evolution 35, 81-90.

Sutherland, W.J., Fleishman, E., Mascia, M.B., Pretty, J. \& Rudd, M.A. (2011). Methods for collaboratively identifying research priorities and emerging issues in science and policy. Methods in Ecology and Evolution 2, 238-247.

Sutherland, W.J., Freckleton, R.P., Godfray, H.C.J., Beissinger, S.R., BENTON, T., CAmeron, D.D., Carmel, Y., CoOmes, D.A., Coulson, T., Emmerson, M.C., Hails, R.S., HAYs, G.C., Hodgson, D.J., HutChings, M.J., Johnson, D., ET AL. (2013). Identification of 100 fundamental ecological questions. Journal of Ecology 101, 58-67.

TANALgo, K.C., TABorA, J.A.G. \& Hughes, A.C. (2018). Bat cave vulnerability index (BCVI): a holistic rapid assessment tool to identify priorities for effective cave conservation in the 
tropics. Ecological Indicators 89, 852-860.

1259

1260

1261

1262

1263

1264

1265

1266

1267

1268

1269

1270

1271

1272

1273

1274

1275

1276

1277

1278

1279

1280

Tierney, S.M., LANGille, B., Humphreys, W.F., Austin, A.D. \& CoOPER, S.J.B. (2018). Massive parallel regression: a précis of genetic mechanisms for vision loss in diving beetles. Integrative and Comparative Biology 58, 465-479.

ToBIN, B.W., Hutchins, B.T. \& SCHWARTZ, B.F. (2013). Spatial and temporal changes in invertebrate assemblage structure from the entrance to deep-cave zone of a temperate marble cave. International Journal of Speleology 42, 203-214.

Torres-PaZ, J., Hyacinthe, C., Pierre, C. \& RÉtauX, S. (2018). Towards an integrated approach to understand Mexican cavefish evolution. Biology Letters 14, 20180101.

Trontelu, P. (2019). Structure and genetics of cave populations. In Cave Ecology (eds T. Moldovan, L. Kováč \& S. Halse), pp. 269-296. Springer, Cham, Switzerland.

TRONTELJ, P., BLEJEC, A. \& FIŠER, C. (2012). Ecomorphological convergence of cave communities. Evolution 66, 3852-3865.

Trontelu, P., Borko, Š. \& Delić, T. (2019). Testing the uniqueness of deep terrestrial life. Scientific Reports 9, 15188.

VenARsky, M.P. \& Huntsman, B.M. (2018). Food webs in caves. In Cave Ecology (eds O. Moldovan, L. KovÁČ \& S. HALSE), pp. 309-328. Springer, Cham, Switzerland.

VenARSKy, M.P., Huryn, A.D. \& Benstead, J.P. (2012). Re-examining extreme longevity of the cave crayfish Orconectes australis using new mark-recapture data: a lesson on the limitations of iterative size-at-age models. Freshwater Biology 57, 1471-1481.

Voituron, Y., De Fraipont, M., Issartel, J., Guillaume, O. \& Clobert, J. (2011). Extreme lifespan of the human fish (Proteus anguinus): A challenge for ageing mechanisms. Biology Letters, 7. 
Vonk, R. \& NiJMAn, V. (2006). Sex ratio and sexual selection in wormshrimps (Crustacea, Amphipoda, Ingolfiellidea). Contributions to Zoology 75, 189-194.

Wakeling, S., Willett, P., Creaser, C., Fry, J., Pinfield, S. \& Spezi, V. (2016). Open-access mega-journals: a bibliometric profile. PLOS ONE 11, e0165359.

Walther, G.-R., Post, E., Convey, P., Menzel, A., Parmesan, C., Beebee, T.J.C., Fromentin, J.-M., Hoegh-GuldberG, O. \& BAirlein, F. (2002). Ecological responses to recent climate change. Nature 416, 389-395.

WILKENS, H. (2020). The role of selection in the evolution of blindness in cave fish. Biological Journal of the Linnean Society 130, 421-432.

WilKens, H. \& STRECKER, U. (2017). Evolution in the dark: Darwin's loss without selection. Springer, Cham, Switzerland.

Wynne, J.J., Bernard, E.C., Howarth, F.G., Sommer, S., Soto-AdAmes, F.N., TAiti, S., Mockford, E.L., Horrocks, M., PAKArati, L. \& PAKarati-Hotus, V. (2014). Disturbance relicts in a rapidly changing world: the Rapa Nui (Easter Island) factor. BioScience 64, 711-718.

Wynne, J.J., Howarth, F.G., SOMmer, S. \& Dickson, B.G. (2019). Fifty years of cave arthropod sampling: techniques and best practices. International Journal of Speleology $\mathbf{4 8 ,}$ $33-48$.

Wynne, J.J., Sommer, S., Howarth, F.G., Dickson, B.G. \& Voyles, K.D. (2018). Capturing arthropod diversity in complex cave systems. Diversity and Distributions 24, 1478-1491. YoshizAwA, M., GORIČKI, Š., SOARES, D. \& JEFFERY, W.R. (2010). Evolution of a behavioral shift mediated by superficial neuromasts helps cavefish find food in darkness. Current Biology 20, 1631-1636. 
Yoshizawa, M., Settle, A., Hermosura, M.C., Tuttle, L.J., Cetraro, N., Passow, C.N. \& MCGAUGH, S.E. (2018). The evolution of a series of behavioral traits is associated with autism-risk genes in cavefish. BMC Evolutionary Biology 18, 89.

ZagmajSTER, M., Culver, D.C. \& SKET, B. (2008). Species richness patterns of obligate subterranean beetles (Insecta: Coleoptera) in a global biodiversity hotspot - effect of scale and sampling intensity. Diversity and Distributions 14, 95-105.

Zagmajster, M., Eme, D., FišEr, C., Galassi, D., Marmonier, P., Stoch, F., Cornu, J.F. \& MALARD, F. (2014). Geographic variation in range size and beta diversity of groundwater crustaceans: Insights from habitats with low thermal seasonality. Global Ecology and Biogeography 23, 1135-1145.

Zagmajster, M., Malard, F., EME, D. \& CUlver, D.C. (2019). Subterranean biodiversity patterns from global to regional scales. In Cave Ecology (eds T. Moldovan, L. KovÁč \& S. HALSE) pp. 195-227. Springer, Cham, Switzerland.

ZAKŠEK, V., DeliĆ, T., FišER, C., JALŽIĆ, B. \& TRONTELJ, P. (2019). Emergence of sympatry in a radiation of subterranean amphipods. Journal of Biogeography 46, 657-669.

Zhang, J., KAPLi, P., PAVlidis, P. \& Stamatakis, A. (2013). A general species delimitation method with applications to phylogenetic placements. Bioinformatics 29, 2869-2876.

\section{SUPPORTING INFORMATION}

Additional supporting information may be found online in the Supporting Information section at the end of the article.

Appendix S1. Questions from List \#2 (i.e. 120 questions selected from List \#1 during Survey\#1) and List \#3 (i.e. 25 additional questions suggested by Survey \#2 participants) ranked based on 
1327 the percentage of 'major importance' votes.

1328 
Table 1. Subject areas, general topics addressed, panel member composition $(*=$ panel

\begin{tabular}{|c|c|c|c|}
\hline Subject area & General topics & Panel members & $\begin{array}{l}\text { Number of } \\
\text { questions }\end{array}$ \\
\hline Adaptation & $\begin{array}{l}\text { Morphological, physiological and } \\
\text { behavioural adaptations to the } \\
\text { subterranean environment }\end{array}$ & $\begin{array}{l}\text { Žiga Fišer }{ }^{\circ} \text {, Daniel W. Fong, Tanja } \\
\text { Pipan*, William R. Jeffery, Jure } \\
\text { Jugovic }\end{array}$ & 10 out of 43 \\
\hline $\begin{array}{l}\text { Origin and } \\
\text { evolution }\end{array}$ & $\begin{array}{l}\text { Cave ontology and past climate } \\
\text { change, migration-speciation- } \\
\text { extinction dynamics, and } \\
\text { speciation and diversification }\end{array}$ & $\begin{array}{l}\text { Steven J.B. Cooper*, Matthew } \\
\text { Niemiller, Alejandro Martínez } \\
\text { Meredith Protas }\end{array}$ & 11 out of 36 \\
\hline $\begin{array}{l}\text { Community } \\
\text { ecology }\end{array}$ & $\begin{array}{l}\text { Population dynamics, community } \\
\text { assembly, biotic interaction, } \\
\text { trophic webs, and energy flows }\end{array}$ & $\begin{array}{l}\text { Rodrigo L. Ferreira*, Cene Fišer, Thais } \\
\text { G. Pellegrini }{ }^{\circ} \text {, Michael Venarsky }\end{array}$ & 4 out of 32 \\
\hline $\begin{array}{l}\text { Macroecology } \\
\text { and } \\
\text { biogeography }\end{array}$ & $\begin{array}{l}\text { Global diversity patterns } \\
\text { (taxonomic, phylogenetic, } \\
\text { functional), biogeography theory, } \\
\text { and diversity drivers }\end{array}$ & $\begin{array}{l}\text { Maria E. Bichuette, David Eme }{ }^{\circ} \\
\text { Florian Malard*, Maja Zagmajster }\end{array}$ & 6 out of 32 \\
\hline $\begin{array}{l}\text { Conservation } \\
\text { biology }\end{array}$ & $\begin{array}{l}\text { Climate change, habitat loss, } \\
\text { invasive species, conservation } \\
\text { and management policies, and } \\
\text { show-cave-related issues }\end{array}$ & $\begin{array}{l}\text { Isabel R. Amorim }{ }^{\circ} \text { Paulo A. V. } \\
\text { Borges*, Louis Deharveng, J. Judson } \\
\text { Wynne, Ana Sofia P. S. Reboleira }\end{array}$ & 12 out of 37 \\
\hline $\begin{array}{l}\text { Microbiology } \\
\text { and applied } \\
\text { topics }\end{array}$ & $\begin{array}{l}\text { Microbial communities, } \\
\text { industrial and pharmaceutical } \\
\text { potential, epidemics, and } \\
\text { exobiology }\end{array}$ & $\begin{array}{l}\text { Naowarat Cheeptham, Thomas M. } \\
\text { Lilley*, Melissa B. Meierhofer }{ }^{\circ} \text {, Diana } \\
\text { E. Northup }\end{array}$ & 7 out of 31 \\
\hline Other topics & $\begin{array}{l}\text { Any topic falling outside the } \\
\text { scope of the six core subject } \\
\text { areas }\end{array}$ & $\begin{array}{l}\text { David C. Culver*, Christian Griebler, } \\
\text { Johanna Kowalko, Raoul Manenti }^{\circ}\end{array}$ & $\begin{array}{l}\mathrm{n} / \mathrm{a} \text { (merged within } \\
\text { the other subject } \\
\text { areas) }\end{array}$ \\
\hline
\end{tabular}


Table 2. Glossary of terms.

1335

\begin{tabular}{|l|l|}
\hline Term & General definition \\
\hline Cave & $\begin{array}{l}\text { A human-accessible subterranean space, either a single chamber or series of chambers, } \\
\text { formed within different substrata (Curl, 1964). Note that a cave is just one among the } \\
\text { wide variety of subterranean habitats (see definition below). }\end{array}$ \\
\hline Exaptation & $\begin{array}{l}\text { A trait shaped by selection or neutral evolution co-opted for a new function (Gould \& } \\
\text { Vrba, 1982). }\end{array}$ \\
\hline Speleogenetic process & $\begin{array}{l}\text { The process of water dissolving surrounding rock, gradually forming passages that } \\
\text { evolve into cave systems (Audra \& Palmer, 2011). }\end{array}$ \\
\hline $\begin{array}{l}\text { Subterranean habitat(s) / } \\
\text { ecosystem(s) }\end{array}$ & $\begin{array}{l}\text { The breadth of underground voids of different sizes, either dry or filled with water, } \\
\text { sharing two main ecological features: the absence of sunlight and buffered climatic } \\
\text { conditions. Examples of subterranean habitats include caves, groundwater, anchialine } \\
\text { systems, artificially excavated underground voids, shallow subterranean habitats, as } \\
\text { well as deep maze of fissures and pore spaces with size prohibiting human entry } \\
\text { (Culver \& Pipan, 2019). }\end{array}$ \\
\hline
\end{tabular}

1336 
Fig. 1. Survey workflow, summary statistics of survey participants, and the breakdown by subject area of the 50 highest priority research questions.

Fig. 2. The relationship between median range size (maximum linear extent) per latitudinal band and latitude for 147 European groundwater species of Niphargidae (Amphipoda) and Aselloidea (Isopoda) delimited using morphology (A) and a molecular species delimitation method (B). Molecular delimitation was performed by a Bayesian implementation of the Poisson tree processes (Zhang et al., 2013) approach based on molecular phylogenies inferred from 2883 cytochrome $c$ oxidase subunit I sequences. Black horizontal bars, dots, and boxes show the median, average, and interquartile range, respectively, for $0.9^{\circ}$ latitudinal bands. The maximum length of each whisker is up to 1.5 times the interquartile range. Trend lines (with $95 \%$ confidence intervals) represent the fit of a gamma generalized linear model to the averages of latitudinal bands and its quadratic (A) and cubic (B) term. Data re-analysed from Eme et al. 1352 (2018). 